DIANA TOGNINI SABA

\title{
DIREITO DE RETENÇÃO E SEUS LIMITES
}

\author{
Dissertação de Mestrado
}

Orientador: Professor Associado Dr. José Fernando Simão

UNIVERSIDADE DE SÃO PAULO

FACULDADE DE DIREITO

São Paulo-SP 
DIANA TOGNINI SABA

\title{
DIREITO DE RETENÇÃO E SEUS LIMITES
}

\begin{abstract}
Dissertação apresentada à Banca Examinadora do Programa de Pós-Graduação em Direito, da Faculdade de Direito da Universidade de São Paulo, como exigência parcial para obtenção do título de Mestre em Direito, na área de concentração Direito Civil, sob a orientação do Prof. Associado Dr. José Fernando Simão.
\end{abstract}

Versão corrigida em 25/04/2016. A versão original, em formato eletrônico (PDF), encontra-se disponível na CPG da Unidade

\section{UNIVERSIDADE DE SÃO PAULO}

FACULDADE DE DIREITO

São Paulo-SP

2016 


\section{DIREITO DE RETENÇÃO E SEUS LIMITES}

Dissertação apresentada à Banca Examinadora do Programa de Pós-Graduação em Direito, da Faculdade de Direito da Universidade de São Paulo, como exigência parcial para obtenção do título de Mestre em Direito, na área de concentração Direito Civil, sob a orientação do Prof. Associado Dr. José Fernando Simão.

Aprovada em:

\section{BANCA EXAMINADORA}

Prof. Dr. José Fernando Simão

Julgamento:

Prof. Dr.

Julgamento:

Prof. Dr.

Julgamento:
Instituição: Universidade de São Paulo

Assinatura:

Instituição:

Assinatura:

Instituição:

Assinatura: 


\section{RESUMO}

SABA, Diana Tognini. Direito de retenção e seus limites. 2016. 322 p. Mestrado Faculdade de Direito, Universidade de São Paulo, São Paulo, 2016.

Diante da necessidade de atualização do estudo relativo ao direito de retenção, uma vez que as grandes obras doutrinárias estrangeiras e nacionais acerca do tema datam do final do século XIX e do início do século XX, abordaram-se as principais controvérsias relativas ao jus retentionis à luz da atual codificação a fim de concluir-se se o instituto ainda encontra justificativa em nosso ordenamento, bem como se seria admitido tal qual concebido em suas origens. Para tanto, procurou-se definir o que entendemos por direito de retenção, delimitando seu campo de atuação, suas características, seus elementos e sua natureza jurídica. Ao longo do estudo, analisou-se essa figura à luz do Código Civil de 2002 e do atual estágio da jurisprudência, concluindo que a previsão legislativa do instituto ainda se justifica, porém merece reforma. Ademais, conclui-se que os limites rígidos em que concebido o direito de retenção devem ser flexibilizados em atenção aos princípios da função social da posse e da boa-fé objetiva para admitir-se a utilização do bem retido em alguns casos.

Palavras-chave: direito de retenção; Código Civil de 2002; posse; elementos essenciais; campo de aplicação; natureza jurídica; efeitos; limites; função social. 


\section{RÉSUMÉ}

SABA, Diana Tognini. Droit de rétention et ses limites. 2016. 322 p. Master en Droit Faculté de Droit, Université de São Paulo, São Paulo, 2016.

Il est nécessaire d'actualiser l'étude du droit de rétention depuis que les grandes œuvres étrangères et nationaux à propos du thème datent de la fin du XIXe siècle et du début du XXème siècle. Ainsi, ce travail adresse les principales controverses concernant le jus retentionis en attention à l'actuelle codification, le but étant de savoir si ce droit trouve encore une justification au sein du système juridique actuel et si celui-ci doit être admis de la même manière comme il était conçu auparavant. Pour parvenir à ces conclusions, il s'agira de définir le concept du droit de rétention, de délimiter son champ d'application, de définir ses caractéristiques ainsi que ses éléments fondamentaux et enfin, sa nature juridique. A travers cette étude, le droit de rétention est analysé au regard des dispositions du Code Civil de 2002 et de l'actuelle jurisprudence. À la fin, on conclut que la prévision législative en la matière se justifie mais il apparaît nécessaire de réformer cette législation. En outre, il apparaît que les strictes limites entourant le droit de rétention dans sa conception originaire doivent être assouplies en égard aux principes de bonne foi et de possession dans sa fonction sociale, afin d'admettre l'utilisation du bien retenu par le rétenteur, dans certains cas.

Mots-clés: droit de rétention; Code Civil de 2002; possession; éléments essentiels ; cadre d'application ; nature juridique ; effets ; limitations ; fonction sociale. 


\section{SUMÁRIO}

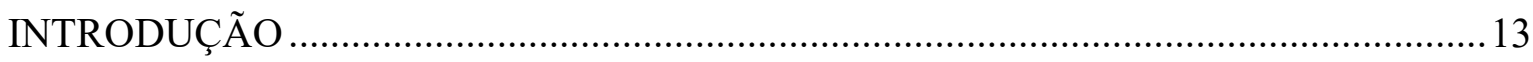

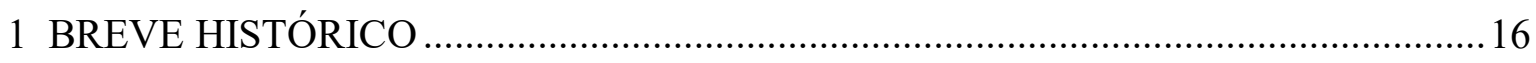

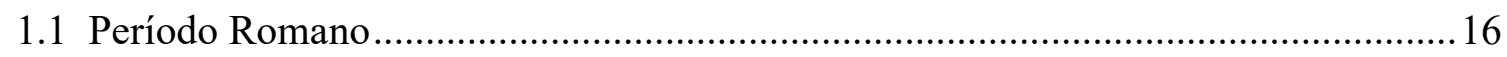

1.2 Período Medieval e Início do Período Moderno .....................................................20

1.3 Direito de retenção na legislação estrangeira .......................................................2 26

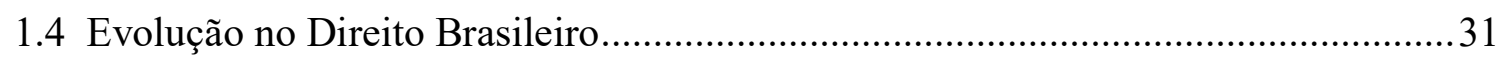

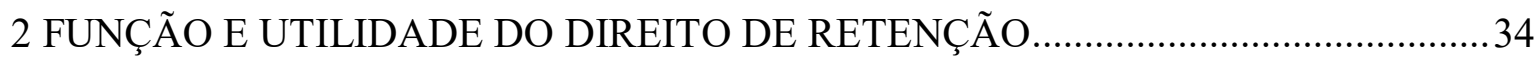

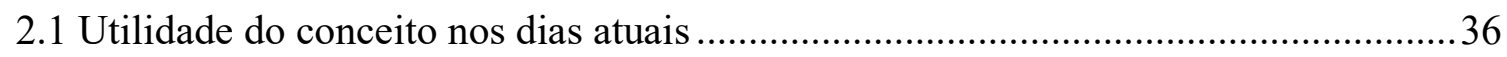

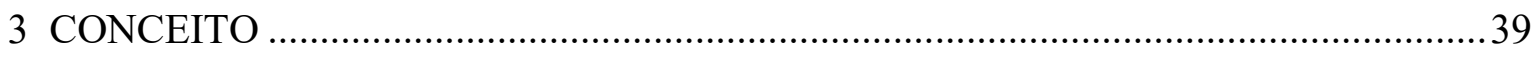

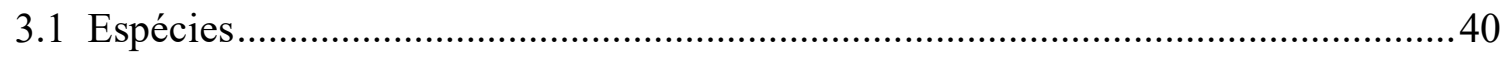

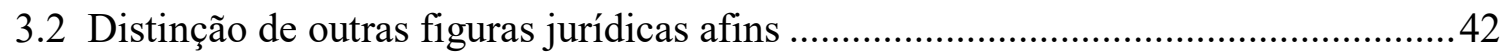

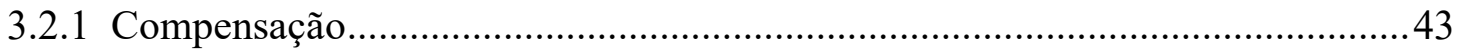

3.2.2 Exceção de contrato não cumprido...................................................................

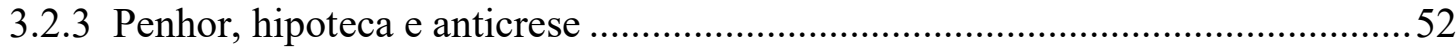

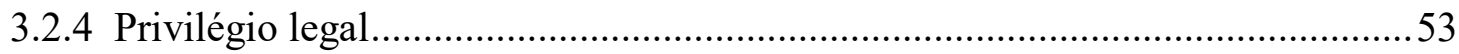

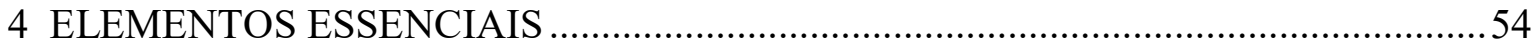

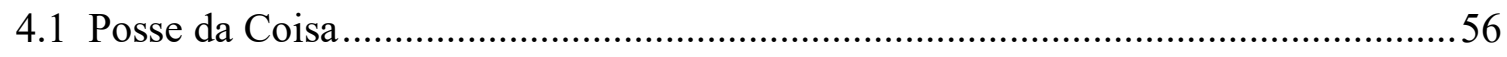

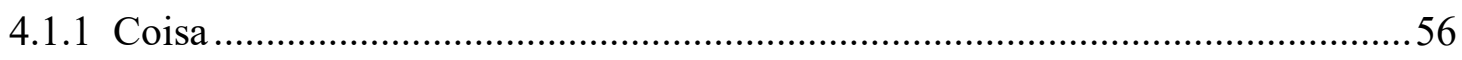

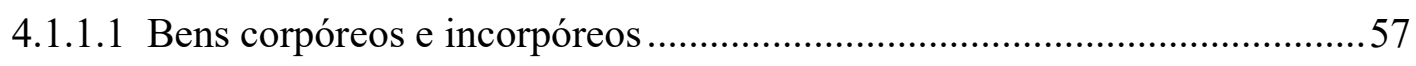

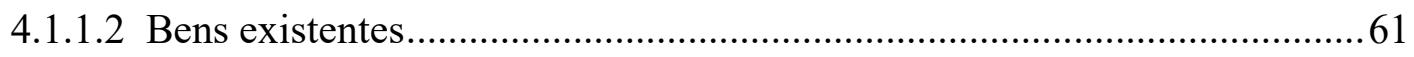

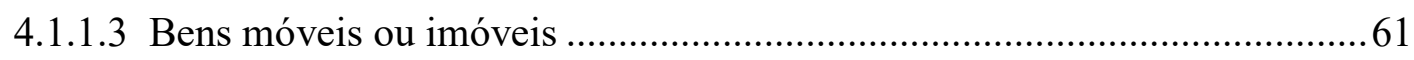

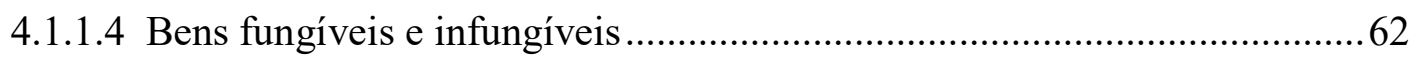

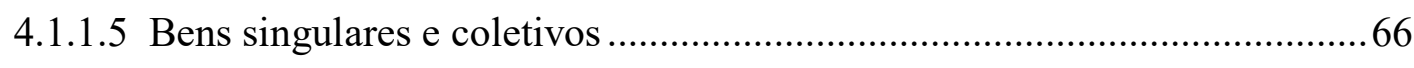

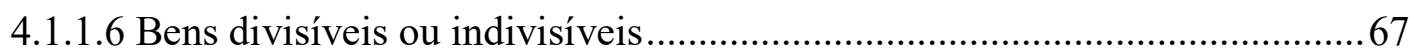


4.1.1.7 Bens in commercio e extra commercio. Bens inalienáveis e impenhoráveis.

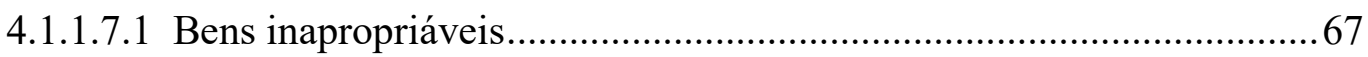

4.1.1.7.2 Bens inalienáveis e impenhoráveis .............................................. 71

4.1.1.7.3 O art. 594 do Código de Processo Civil de 1973 .................................. 73

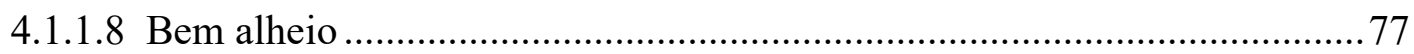

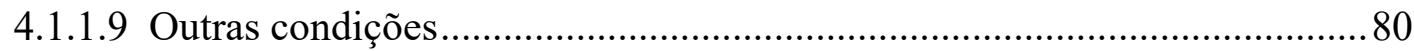

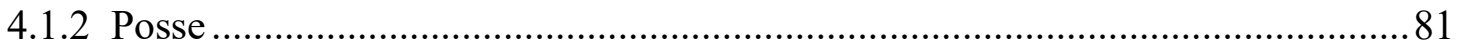

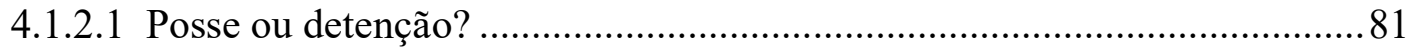

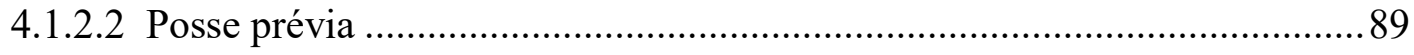

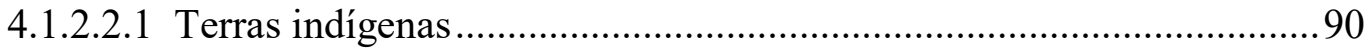

4.1.2.3 Manutenção da posse …..........................................................................96

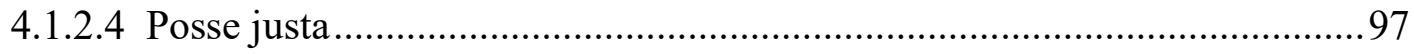

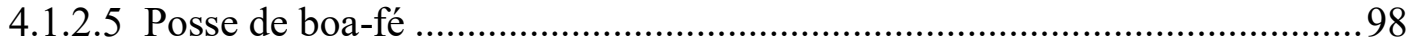

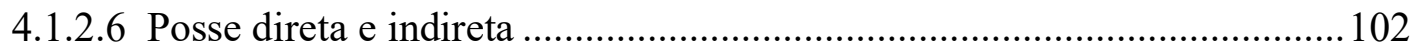

4.1.2.7 Posse exercida por meio de representante ............................................. 103

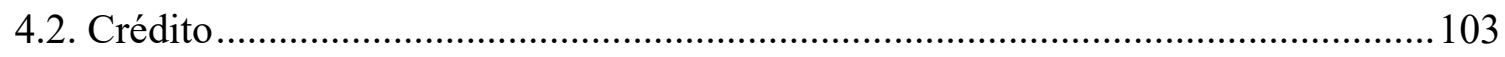

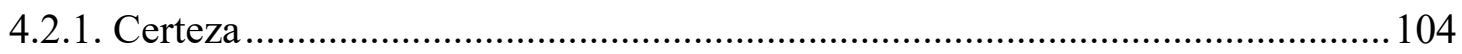

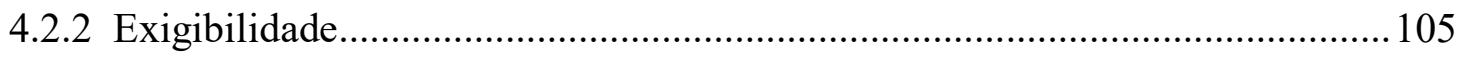

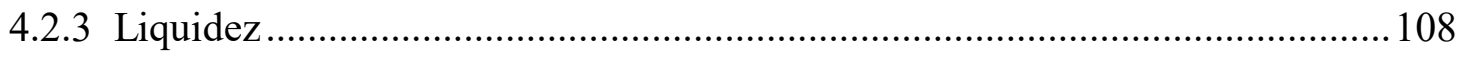

4.3 Conexidade entre o crédito e a coisa ou a relação jurídica através da qual sua posse

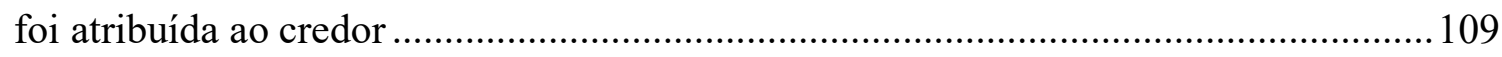

4.3.1 A conexidade como elemento do direito de retenção .......................................110

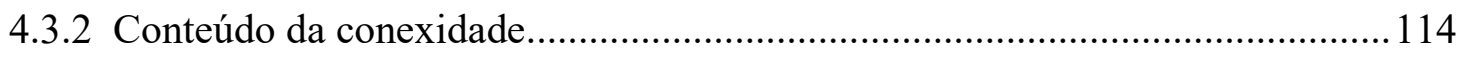

4.3.3 Direito de retenção por conexidade jurídica versus exceção de contrato não

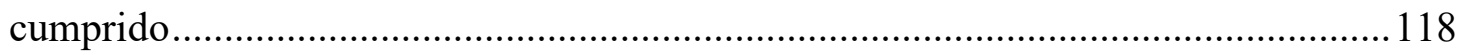

4.3.4 Conexidade no ordenamento brasileiro .................................................... 125

4.3.5. Direito de retenção: unidade ou pluralidade? ................................................. 128 
4.4 Inexistência de exclusão do direito de retenção

5 FUNDAMENTO JURÍDICO E LIMITES DE ADMISSIBILIDADE DO DIREITO DE

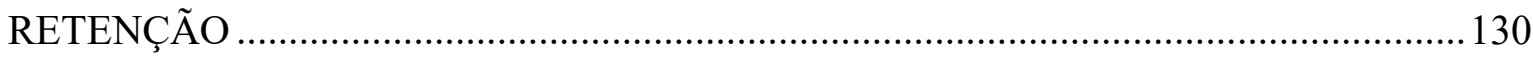

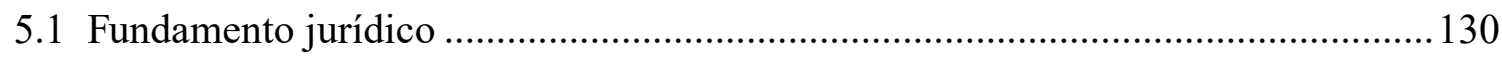

5.1.1. Boa-fé objetiva como fundamento moderno do direito de retenção .................134

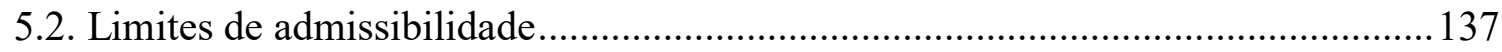

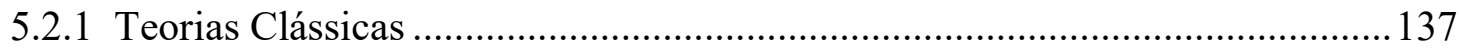

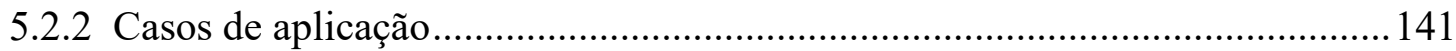

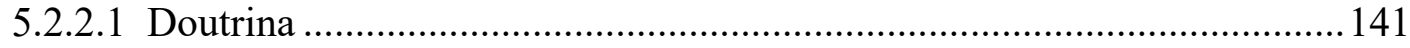

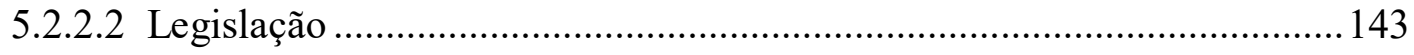

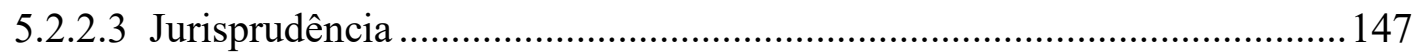

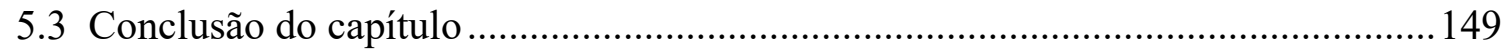

6 CARACTERÍSTICAS DO DIREITO DE RETENÇÃO................................................ 160

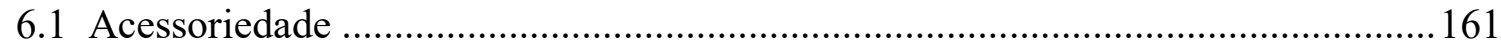

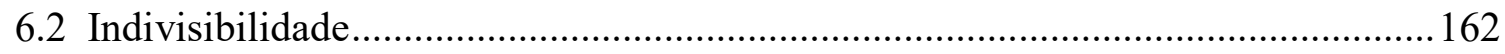

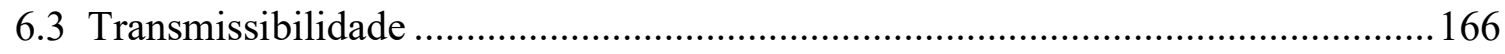

6.3.1. Pode o direito de retenção ser cedido sem que haja a transmissão do direito

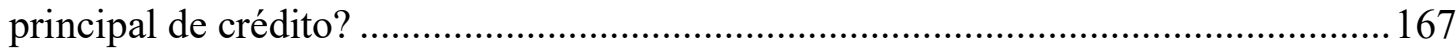

6.3.2. Aplicação das regras do Código Civil relativas à cessão de crédito e à assunção

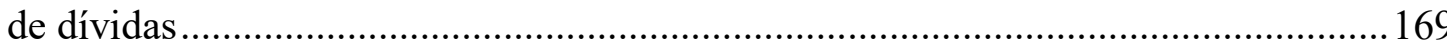

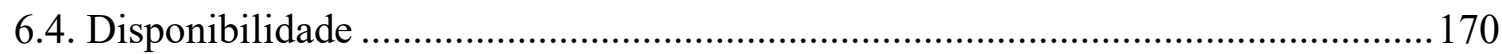

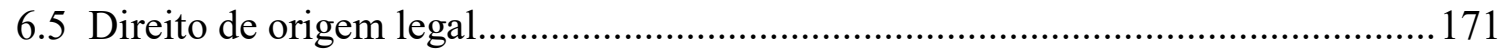

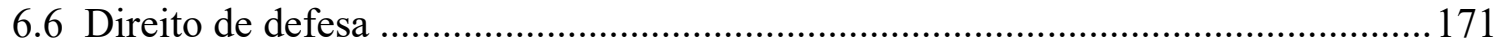

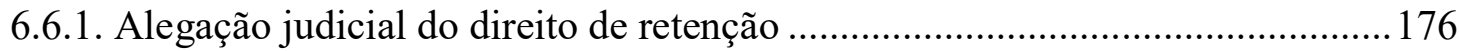

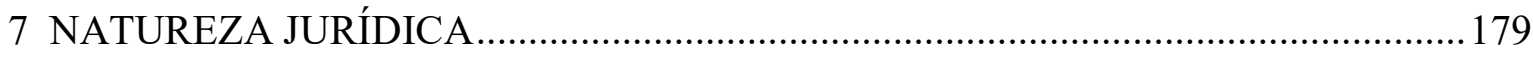

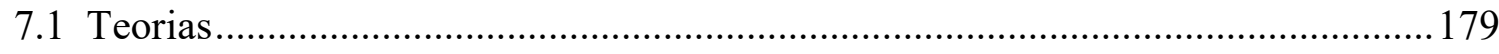

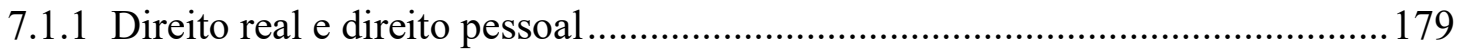

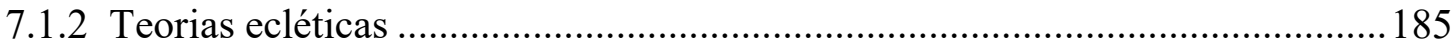


7.2 Distinção entre direitos reais e pessoais na doutrina.

7.3 Direito de retenção é direito subjetivo?

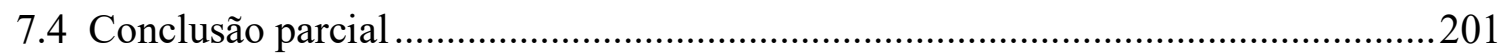

7.5 Direito de retenção e direito internacional privado ................................................204

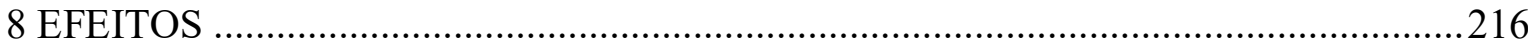

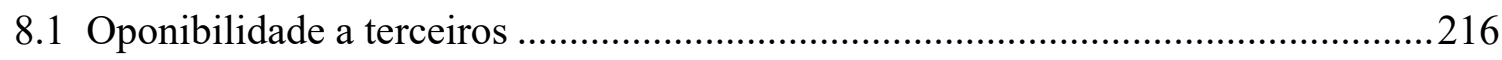

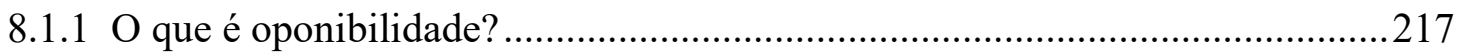

8.1.2 Teorias acerca da eficácia do direito de retenção ...........................................224

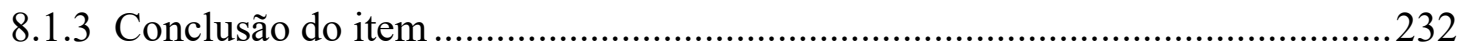

8.1.3.1 A oponibilidade e os bens de terceiros ...............................................242

8.1.4 Oponibilidade e a questão do registro público .............................................245

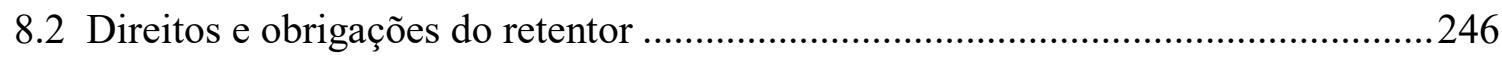

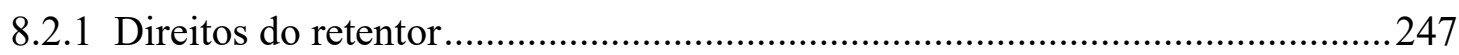

8.2.1.1 Proteção possessória .......................................................................247

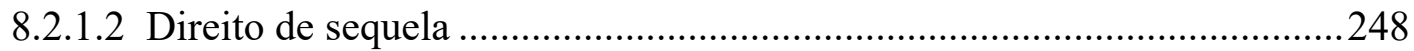

8.2.1.3 Direito de repetição do bem entregue com base em erro..........................250

8.2.1.4 Direito de reter os bens acessórios à coisa retida..................................252

8.2.1.4.1 O problema dos frutos não suscetíveis de conservação.....................254

8.2.1.5 Direito de exigir o reembolso pelas despesas havidas com a conservação do bem retido ou o ressarcimento de um prejuízo por ele causado durante a retenção

8.2.1.5.1 Responsabilidade pelo pagamento de tributos e obrigações propter rem incidentes sobre o bem durante a retenção

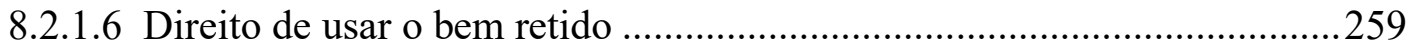

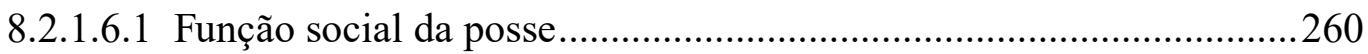

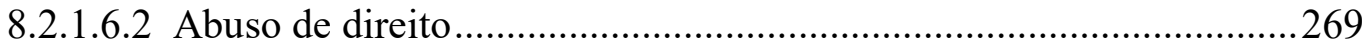

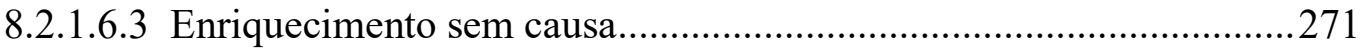

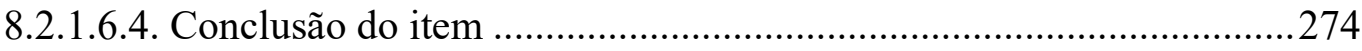


8.2.1.7. Limitação temporal do exercício do direito de retenção?......

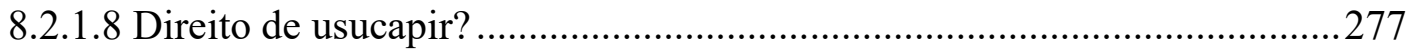

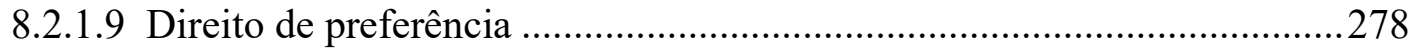

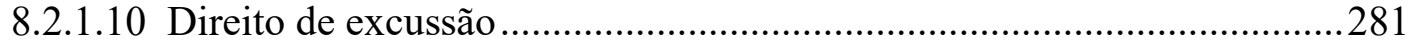

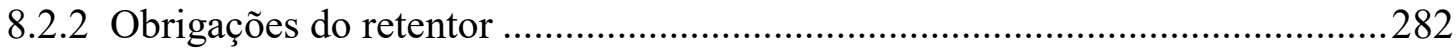

8.2.2.1 Obrigação de conservar o bem no estado em que a recebeu.....................282

8.2.2.2 Obrigação de restituir o bem, com seus frutos e acessórios, após o

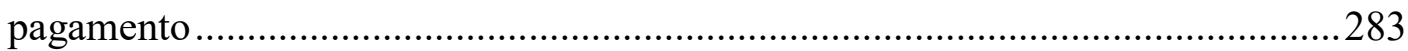

8.2.2.3 Obrigação de indenizar os prejuízos a que tenha dado causa ....................283

8.2.2.3.1 Bens tendentes à deterioração........................................................284

8.2.2.4 Obrigação de entregar a diferença de preço no caso de execução do bem retido

9 EXTINÇÃO DO DIREITO DE RETENÇÃO.............................................................28

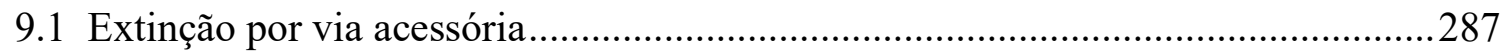

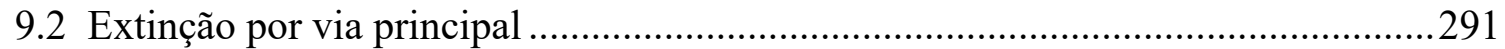

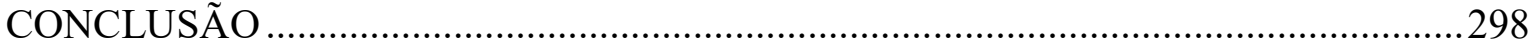

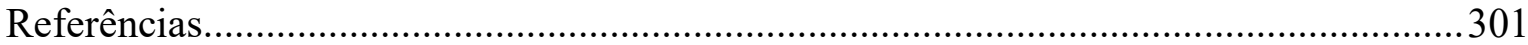




\section{INTRODUÇÃO}

O direito de retenção pode ser definido como o direito assegurado ao possuidor, obrigado a restituir um bem, de reter a coisa em garantia, prolongando a sua posse para além do momento em que deveria cessar, até que seu credor quite integralmente débito, relacionado à coisa em si ou à sua posse, que tenha para com ele.

Seu conceito, contudo, é um dos poucos pontos sobre os quais não existe viva controvérsia. Embora seja assunto bastante debatido entre doutrinadores e também na jurisprudência, há divergências sobre praticamente tudo que a ele se relaciona: desde seus antecedentes históricos até seus efeitos, de seus elementos essenciais à sua natureza jurídica, tornando-o um dos institutos mais obscuros do direito civil.

Como salienta Olavo de Andrade ${ }^{1}$ :

É assumpto juridico que offerece grandes difficuldades, em sua noção e fundamento, interpretação doutrinaria, caracteres genericos e especificos, natureza juridica e applicações, o que diz respeito ao direito de retenção - jus retentionis - e poucos institutos como este tem sido objeto de maiores controversias.

Essas controvérsias foram melhor abordadas e desenvolvidas na Europa continental, entre o final do século XIX e o início do século XX. Não obstante, jamais se chegou a uma solução de consenso para as questões levantadas, sendo que a matéria permanece, ainda hoje, com contornos bem pouco definidos.

Entre nós, não muito numerosos foram os autores que se dedicaram a estudar o assunto objetivamente, tendo a maioria dos doutrinadores nacionais limitado-se a dedicar poucas páginas de seus manuais à menção do instituto. Ademais, seus estudos foram realizados à luz da antiga legislação civil, merecendo atualização.

A matéria, portanto, não é, como poderia parecer, datada e nem perdeu sua importância ao longo do tempo. O direito de retenção é previsto ainda hoje em nosso ordenamento, não só no Código Civil, como também na legislação esparsa. Além disso, é objeto de inúmeras discussões nos tribunais brasileiros ${ }^{2}$. Dessa forma, surge como assunto

1 ANDRADE, Olavo de. Notas sobre o direito de retenção. São Paulo: Livraria Academica Saraiva \& C. Editores, 1922, p. 11.

2 Ao realizar-se um levantamento de decisões de mérito dos Tribunais Superiores que abordaram o assunto "retenção", foram encontrados 457 resultados do Supremo Tribunal Federal (compreendidos no período de 1957 - a data de corte corresponde ao ano da última edição do livro de Arnoldo Medeiros da Fonseca, consultada para o presente trabalho, pois as obras doutrinárias já traziam decisões anteriores a este marco, sendo desnecessária a consulta por meio do site - a 30.09.2015) e 2.290 resultados do Superior Tribunal 
pouco explorado sobre o qual ainda pairam inúmeras dúvidas a serem resolvidas à luz das atuais doutrina e legislação.

Justifica-se, assim, a elaboração de estudo dedicado à análise do direito de retenção em todos os seus aspectos, procurando atualizar e contextualizar as discussões históricas, bem como trazer novas problematizações à matéria.

O estudo inicia-se, portanto, com um breve histórico do direito de retenção, cujas origens, para a maioria dos autores, remontam aos tempos romanos, tendo o instituto sobrevivido até os dias de hoje assumindo diversas configurações ao longo do tempo. Nesse tópico, será abordada a evolução do direito de retenção no direito brasileiro, bem como a sua inserção na legislação estrangeira.

A função de garantia do direito de retenção torna-se, então, bastante clara, merecendo certo destaque, já que é um ponto central do estudo desta figura e deve informar o intérprete que for fazer uso dela. No mesmo tópico, defende-se a utilidade da manutenção do instituto na legislação civil atual.

Após, no Capítulo 3, definir-se-á o que hoje se entende por direito de retenção, tema sobre o qual, como visto, há excepcionalmente certo consenso entre os doutrinadores. Ademais, como forma de complementar a conceituação do instituto, será necessário diferenciar as duas espécies de direito de retenção normalmente apontadas pela doutrina (direito de retenção convencional e direito de retenção propriamente dito) e também distinguir esse instituto de outras figuras jurídicas afins, como a compensação e a exceptio non adimpleti contractus.

Analisar-se-ão igualmente os elementos essenciais do direito de retenção (Capítulo 4), sendo expostas as características essenciais à coisa e a sua posse, ao crédito e à conexidade, que nada mais é do que o elo que une o crédito e o bem.

Em seguida, no Capítulo 5, serão abordados o fundamento jurídico e os limites de admissibilidade do direito de retenção, buscando-se resolver uma das maiores controvérsias que cercam a matéria, qual seja: a possibilidade de o direito de retenção ser exercido além dos limites em que vem expressamente previsto na legislação.

de Justiça (compreendidos no período de 2002 - data da entrada em vigor do atual Código Civil - a 30.09.2015). Foram as decisões consultadas, a partir da leitura dos acórdãos, para aferir (i) se efetivamente referiam-se ao direito de retenção propriamente dito, e (ii) se o Tribunal Superior havia se manifestado sobre o referido instituto ou se o julgamento fora restrito a aspectos meramente processuais. As principais decisões consultadas foram colacionadas ao longo deste estudo, de forma a ilustrar e embasar as conclusões delineadas. 
Serão expostas também as principais características (Capítulo 6) tradicionalmente atribuídas ao instituto.

Depois, um capítulo será dedicado ao igualmente controverso estudo da natureza jurídica do direito de retenção. O ponto demandará atenção, já que depende da definição de critérios diferenciadores dos direitos reais e pessoais, questão vivamente debatida até os dias atuais.

Em seguida, tratar-se-á dos efeitos desse instituto, procurando compatibilizar a visão de outrora com as inovações de nossa legislação, mormente no tocante à importante discussão acerca de sua oponibilidade a terceiros e à utilização do bem pelo retentor, analisando-se a possibilidade de mitigação dos rígidos efeitos tradicionalmente atribuídos ao instituto.

Por fim, no Capítulo 9 elencam-se os modos de extinção desse direito normalmente identificados pela doutrina.

O presente estudo, como já mencionado, é realizado à luz dos novos paradigmas do direito civil introduzidos no Código Civil, cuja comissão foi presidida por Miguel Reale e inseridos também na Constituição da República. Buscou-se, outrossim, realizar um estudo abrangente do direito de retenção, focado não apenas na doutrina clássica, mas também na legislação estrangeira e na farta jurisprudência pátria a respeito do tema, estabelecendo-se ligações interdisciplinares sempre que possível, abordando-se, ao longo do estudo, temas afetos ao direito administrativo, ao direito do trabalho e mesmo ao direito internacional privado, com o intuito de obter-se, ao final, uma visão ampla acerca do direito de retenção. 


\section{CONCLUSÃO}

Muitas controvérsias cercam o estudo do direito de retenção. Nesta dissertação buscou-se, após um pequeno introito histórico, resolver algumas dessas questões à luz dos dispositivos do Código Civil de 2002, de forma a atualizar a discussão sobre o tema.

Lamentavelmente, o referido diploma não disciplina o direito de retenção de forma geral e em capítulo específico, na contramão da tendência mais atual com relação à matéria. Merece, portanto, reforma nossa legislação civil. Não obstante, a partir da análise dos artigos em que previsto no Código Civil, conjugados com uma interpretação sistemática e consideração da extensa literatura sobre o assunto, foi possível extrair algumas conclusões a respeito da configuração dessa garantia no Brasil.

Em primeiro lugar, dentro da lógica funcionalista que envolve todo o Código Civil, ressaltou-se a função de garantia exercida pelo direito de retenção, demonstrando-se a sua utilidade no ordenamento.

Em seguida, demonstrou-se que o conceito de direito de retenção é unívoco, porém existem controvérsias quanto às espécies de direito de retenção que devem ser compreendidas no estudo. Definiu-se, nesse sentido, que apenas o direito de retenção propriamente dito, derivado de título novo, e não a mera faculdade de retenção, constitui objeto desse estudo. Nesse capítulo buscou-se ainda traçar as diferenças em relação a outras figuras afins, como a compensação e a exceptio non adimpleti contractus, diferenciação que foi aprofundada ao longo do estudo. Assim, distinguiu-se o direito de retenção da exceptio non adimpleti contractus, uma vez que esta incide entre prestações simalagmáticas, enquanto aquele incide entre prestações e deveres surgidos no bojo de relações contratuais não sinalagmáticas, ainda que se trate de contrato bilateral. Com relação à compensação, entendeu-se que esta deve ser exercida com prioridade, por se tratar de meio de extinção da obrigação, enquanto o direito de retenção é mera garantia.

Com relação aos seus elementos essenciais, determinou-se que a retenção só pode recair sobre bens corpóreos, existentes, alheios, móveis ou imóveis, fungíveis ou infungíveis, singulares ou universalidades de fato, divisíveis ou indivisíveis. Definiu-se, ainda, que as coisas inapropriáveis, os bens públicos, podem eventualmente constituir objeto deste direito, assim como, a princípio, as coisas inalienáveis e impenhoráveis, desde 
que a retenção não prejudique a causa da inalienabilidade ou impenhorabilidade, tal como ocorre com os bens de família.

Determinou-se, ainda, que apenas a posse pode dar ensejo à retenção no ordenamento brasileiro, excluindo-se a hipótese de esse direito vir a ser exercido pelo mero detentor. Demonstrou-se, ainda, que a posse deve ser prévia ao exercício da garantia, bem como deve ser de boa-fé, justa e direta.

O crédito, por sua vez, deve ser, certo e exigível, mas não há necessidade de ser líquido.

Ao final da análise dos elementos essenciais do instituto que é objeto deste estudo, concluiu-se que, no Brasil, o direito de retenção pode ser exercido tanto com base na conexidade material, quanto com base na conexidade jurídica.

Com relação aos limites de admissibilidade dessa figura, definiu-se primeiramente que o fundamento do direito de retenção, na atualidade, é o princípio da boa-fé objetiva, porém sustentou-se igualmente que esse fundamento não deveria influenciar a definição dos limites em que admitida a figura. Assim, buscou-se critério mais científico para definir em que casos é possível invocar-se o jus retentionis no direito brasileiro. Nesse sentido, restou demonstrado que o Código Civil traz, no seu artigo 1.219, uma cláusula geral de aplicação desse instituto com base na conexidade material, sendo certo ainda que, a partir da análise da doutrina, da legislação e da jurisprudência nacionais, concluiu-se ser também possível defender sua aplicação extensiva aos casos não tipificados e previstos expressamente em lei nas hipóteses de conexidade material por dano e jurídica, por meio da analogia, seja ela legis ou iuris.

Abordou-se, em seguida, algumas das características clássicas atribuídas ao direito de retenção, como sua indivisibilidade e transmissibilidade. Nesse capítulo, tangenciou-se também a forma como o direito de retenção deve ser arguido em juízo.

No Capítulo 7, abordou-se o tema que gerou mais controvérsia em relação ao jus retentionis, qual seja, a sua natureza jurídica. Relacionaram-se todas as correntes surgidas em torno do tema e investigou-se, incidentalmente, a diferenciação doutrinária entre direitos reais e pessoais, bem como os elementos que caracterizam os direitos subjetivos. Ao final, concluiu-se que a retenção é, no ordenamento brasileiro, direito subjetivo e pessoal. 
Ainda neste capítulo, ressaltou-se que, sob o prisma do direito internacional privado, o importante é definir a regra de qualificação interna aplicável ao direito de retenção, concluindo-se que, no ordenamento brasileiro, ser-lhe-iam aplicáveis duas regras: a do art. $9^{\circ}$ da LINDB quando surgisse no bojo de uma relação obrigacional prévia, e a do art. $8^{\circ}$ da LINDB quando alegado por possuidor que não mantinha relação prévia com o reivindicante.

Em seguida, iniciou-se o estudo de seus efeitos a partir de considerações acerca de sua oponibilidade a terceiros, tema que enseja, há séculos, grande controvérsia doutrinária. Concluiu-se, ao final, pela oponibilidade do direito de retenção a terceiros, admitindo-se apenas limitações quando: (i) em colisão com direito que lhe prefere em se tratando de credor insolvente; (ii) há garantia anteriormente constituída; (iii) a lei assim determinar ou (iv) exercido por conexidade jurídica, o contrato não produzir efeitos com relação ao titular reivindicante do bem entregue ao retentor. Demonstrou-se, outrossim, que a publicidade do direito de retenção dá-se por seu próprio exercício, dispensando-se o registro.

Numa segunda parte, abordaram-se os direitos e deveres do retentor, defendendose, na parte mais proeminente, que deve ser flexibilizada a proibição de o retentor utilizar o bem retido, em atenção aos princípios da função social da posse, da boa-fé objetiva e também do enriquecimento sem causa. Tal conclusão, já adotada pelos Tribunais Superiores em precedentes ali citados, impede que a posse sem qualquer destinação social prolongue-se ad infinitum, o que atende às expectativas do credor de ver-se pago e também do devedor de receber o bem que lhe é devido.

Por fim, elencaram-se os meios de extinção tradicionalmente reconhecidos ao direito de retenção.

Procurou-se, assim, ao longo da obra, não só apresentar as diversas posições doutrinárias surgidas a respeito do tema, como também resolver alguns desses impasses à luz dos dispositivos da atual legislação e jurisprudência brasileira e estrangeira e em consideração à multidisciplinariedade essencial ao estudo empreendido. Essas conclusões não só visam, na medida do possível, garantir maior eficácia ao instituto, como também pretendem apresentar um guia contemporâneo para aplicação prática e renovada dessa garantia. 


\section{REFERÊNCIAS}

1 LiVRos, MONOGRAFIAS E ARTIGOS

ABRANTES, José João. A exceção de não cumprimento do contrato no direito civil português. Coimbra: Almedina, 1986.

ABREU, Jorge Manuel Coutinho de. Do abuso de direito: ensaio de um critério de direito civil e nas deliberações sociais. Coimbra: Almedina, 1999.

AGOURRAM-ELMENJRA, Khadija. Le droit de rétention en droit marocain. Casablanca: Université Hassan II, 1988.

AGUIAR JUNIOR, Ruy Rosado de. Jornada de Direito Civil. Brasília: CFJ, 2007.

ALMEIDA, Francisco de Paula Lacerda de. Obrigações: exposição systematica desta parte do direito civil patrio em seguimento aos "direitos de família" e "direito das cousas" do Conselheiro Lafayette Rodrigues Pereira. Porto Alegre: Typographia de Cesar Reinhardt, 1897.

ALMEIDA, L. P. Moitinho de. Enriquecimento sem causa. reimpressão da 3. ed. Coimbra: Almedina, 2007.

ALPA, Guido. Compendio del nuovo diritto privato. Torino: UTET, 1985.

ALPA, Guido; BESSONE, Mario. Elementi di direito privato. Roma: Laterza, 2001.

ALVES, José Carlos Moreira. Posse: estudo dogmático. 2. ed. Rio de Janeiro: Forense, 1999, v. 2. t. 1.

A Detenção no Direito Civil Brasileiro: conceito e casos. In: CAHALI, Yussef Said [coord.]. Posse e Propriedade: doutrina e jurisprudência. São Paulo: Saraiva, 1987 p. 1-32.

. Direito romano. 14. ed. Rio de Janeiro: Forense, 2007.

. Direito subjetivo, pretensão e ação. Revista de Processo, v. 12, n. 47, p. 109-123, jul./set. 1987.

ALVIM, Agostinho. Do enriquecimento sem causa. Revista Forense, Rio de Janeiro, v. 54, n. 173, p. 47-67, set./out. 1957.

. Da equidade. Revista dos Tribunais, São Paulo, v. 91, n. 797, p. 796-770, mar. 2002

ALVIM, Arruda. A função social da propriedade, os diversos tipos de direito de propriedade e a função social da posse. In: VENOSA; GAGLIARDI; NASSER [coord.]. 10 anos do código civil: desafios e perspectivas. São Paulo: Atlas, 2012, p. 568-598.

AMARAL, Francisco. Direito civil: introdução. 6. ed. Rio de Janeiro: Renovar, 2006. 
AMARAL NETO, Francisco dos Santos. A equidade no código civil brasileiro. Revista CEJ, Brasília, v. 8, n. 25, p. 16-23, abr./jun. 2004.

AMERICANO, Jorge. Ensaio sobre o enriquecimento sem causa: os institutos de direito em que se manifesta a condenação do locupletamento injustificado. São Paulo: Saraiva, 1933.

AMM-CHABTINI, Alice Al-. Le droit de rétention et l'exceptio non adimpleti contractus en droit libanais. 1987. Tese de doutorado - Université de Paris X Nanterre, Paris, 1987.

ANCEL, Pascal. Droit des sûretés. 7ème ed. Paris: LexisNexis, 2014.

ANDRADE, Darcy Bessone de Oliveira. Aspectos da evolução da teoria dos contratos. São Paulo: Saraiva, 1949.

. Direitos reais. São Paulo: Saraiva, 1988.

ANDRADE, Manuel A. Domingues de. Teoria geral das obrigações. 3. ed. Coimbra: Almedina, 1966.

. Teoria geral da relação jurídica. Coimbra: Almedina, 1983, v. 1.

ANDRADE, Olavo de. Notas sobre o Direito de Retenção. São Paulo: Livraria Academica Saraiva \& C. Editores, 1922.

ANJOS FILHO, Robério Nunes. Breve balanço dos direitos das comunidades indígenas: alguns avanços e obstáculos desde a Constituição de 1988. In: DANTAS; CUNHA JÚNIOR; TAVARES et al. [orgs.]. Desafios do constitucionalismo brasileiro. Salvador: Juspodium, 2009, p. 243-295.

. Direito ao desenvolvimento de comunidades indígenas no Brasil. 2009. Tese de doutorado - FDUSP. São Paulo, 2009.

ARNAUD, Joseph-Louis. Des droits du vendeur d'immeubles non payé en droit romain et en droit français. Dijon : Imprimerie et Lithographie de F. Carré, 1880.

ARZUA, Guido. Posse: o direito e o processo. 2. ed. São Paulo: Revista dos Tribunais, 1978.

ASCENSÃO, José de Oliveira. A tipicidade dos direitos reais. Lisboa: Minerva, 1968. . As relações jurídicas reais. Lisboa: Morais, 1962. . Direitos reais. Lisboa: Centro Est. Dir. Civil, Ed. Univ. Lisboa, 1971.

ASSIS, Araken de. Comentários ao código de processo civil: Lei $n^{\circ} 5.869$, de 11 de janeiro de 1973. 3. ed. Rio de Janeiro: Forense, 2009, v. 6.

. Manual da execução. 12. ed. São Paulo: Revista dos Tribunais, 2009.

AUBRY, Charles; RAU, Charles. Cour de droit civil français: d'après la méthode de Zachariae. 5ème ed. Paris: Marchal et Billard, 1900, t. 3.

AYNĖS, Augustin. Le droit de rétention : unité ou pluralité. Paris: Economica, 2005.

AZEVEDO, Álvaro Villaça. Bem de Família: com comentários à Lei 8.009/90. 4. ed. São Paulo: Revista dos Tribunais, 1999. 
- Conceito de ato ilícito e o abuso de direito. In: RODRIGUES JUNIOR; MAMEDE; ROCHA [coord.]. Responsabilidade civil contemporânea: em homenagem a Sílvio de Salvo Venosa. São Paulo: Atlas, 2001, p. 61-74.

AZEVEDO, Antonio Junqueira de. Estudos e pareceres de direito privado. São Paulo: Saraiva, 2004.

BAILly, Albert. Du droit de rétention à Rome et en France. Paris : A. Giard et E. Brière, 1892.

BARCLAY, Thomas; DAINVILLE, Emmanuel. Les effets de commerce dans le droit anglais : la lettre de change, le chèque et le billet à ordre comparés avec les principales législations étrangères, suivi d'une traduction de la loi anglaise du 18 août 1882 et des principaux articles de la loi du 10 août 1882 sur la capacité de la femme mariée en Angleterre. Paris : A. Durand et Pedone-Lauriel, 1884.

BARRY, Paul. Le droit de rétention en droit civil français. Paris: Arthur Rousseau, 1900.

BASSO, Maristela. Curso de direito internacional privado. 2. ed. São Paulo: Atlas, 2011.

BAUDRY-LACANTINERIE, Marie Paul Gabriel; BARDE, L. Trattato teorico-pratico di diritto civile: delle obligazioni. Milano: Francesco Vallardi, [s.d.], v. 2, tradução da $3^{\text {a }}$ edição original.

BELTRAME, José Alonso. Dos embargos do devedor: teoria e jurisprudência. 3. ed. São Paulo: Revista dos Tribunais, 2002.

BENADIBA, Aurore. Le droit de rétention en France et au Québec : une sûreté mobilière fonctionnelle. Les Cahiers de droit, v. 54, n. 1, p. 115-143, mars/2013. Disponível em http://id.erudit.org/iderudit/1014286ar, acessado pela última vez em 21.06.2015, às $8 \mathrm{~h} 42$.

BEVILAQUA, Clóvis. Direito das Coisas. Brasília: Senado Federal, Conselho editorial, 2003, v.1.

. Principios elementares de direito internacional privado. 2. ed. Rio de Janeiro: Freitas Bastos, 1934.

BIANCHI, Emilio. Dei privilegi e delle cause di prelazione del credito in generale. 2a ed., Napoli: E. Marghieri, 1916.

BOBES, Panaït. Les cas d'application du droit de rétention. Paris : V. Giard et Brière, 1913.

BOBBIO, Norberto. Teoria do ordenamento jurídico. tradução. São Paulo: Edipro, 2011.

BONELLI, Gustavo. Del fallimento: commento al Codice di Commercio. 3a ed. Milano: Francesco Villardi, 1938, vol. 1.

BOSSERT, Paul. Des droits du vendeur d'effets mobiliers non payé. Paris : L. Larose, 1899.

BOURGUIGNON, Álvaro Manoel Rosindo. Embargos de retenção por benfeitorias: e outras questões relativas ao exercício judicial do direito de retenção por benfeitorias. São Paulo: Revista dos Tribunais, 1999. 
BRACQ, Artur. Le droit de rétention : en droit allemand et en droit français. Bordeaux: Y. Cadoret, 1907.

BRÉMOND, Jules. Du droit de rétention. Paris: F. Pichon, 1874.

BROWN, William C. The due process challenge to possessory lien enforcement. Tulsa Law Journal, v. 10, n. 415, p. 415-426, 1974-1975.

BUGNIET, H. Traité du bornage, de la revendication et du droit de rétention. Paris : Marchal, Billard et Cie., 1877.

BUNAZAR, Maurício. Obrigação propter rem: aspectos teóricos e práticos. São Paulo: Atlas, 2014.

BUTERA, Antonio. Del diritto di ritenzione. Roma: Foro Italiano, 1937.

CABRILlAC, Michel; MOULY, Christian; CABRILLAC, Séverine; PÉTEL, Philippe. Droit des sûretés. 9ème ed. Paris: LexisNexis Litec, 2010.

CABRYE, Émile D. Du droit de rétention: droit romain, ancien droit français, droit actuel. Paris: A. Durand, 1860.

CAMAÑO ROSA, Antonio. Derecho de retención: en las legislaciones civil, comercial, procesal y rural; la doctrina y la jurisprudencia uruguayas. Montevideo: Casa A. Barreiro y Ramos, 1941.

CANO MARTÍNEZ DE VELASCO, José Ignacio. La retención de cosa ajena. Barcelona: Bosch, 1990.

CASSIN, René. De l'exception tirée de l'inexécution dans les rapports synallagmatiques (exception non adimpleti contractus) : et de ses relations avec le droit de rétention, la compensation et la résolution. Paris: Sirey, 1914.

CAZELLES, P. Du gage : en droit romain ou en droit français. Paris : Amand Giard, 1882.

CHIEKH RADHI, Younis al-. Le droit de rétention d'après les législations française et suisse. Lausanne : Georges Conne, 1957.

CHIRONI, Giampietro. Trattato dei privilegi, delle ipoteche e del pegno. $2 \mathrm{a}$ ed. Milano, Torino: Bocca, 1917, v.1.

CINTRA, Antonio Carlos de Araújo. GRINOVER, Ada Pellegrini. DINAMARCO, Cândido Rangel. Teoria geral do processo. 27. ed. São Paulo: Malheiros, 2011.

CLAUDE, Jules. De l'exception de dol en droit romain. Des dons manuels en droit français. Nancy : Imprimerie Nancéienne, 1884.

COLIN, Ambroise; CAPITANT, Henri. Cours élémentaire de droit civil français. 10e ed. Paris: Dalloz, 1948, t. 2.

COMPARATO, Fábio Konder. Função social da propriedade dos bens de produção. Revista de Direito Mercantil, Industrial, Econômico e Financeiro, São Paulo, v. 25, n. 63, p. 71-79, jul./set. 1986.

CORDEIRO, António Manuel da Rocha e Menezes. Da boa fé no direito civil. Coimbra: Almedina, 2011.

Tratado de direito civil português. 2. ed. Coimbra: Almedina, 2002, v. 1, t. 2. 
Tratado de direito civil português. Coimbra: Almedina, 2009, v. 2, t. 1.

Tratado de direito civil. 4. ed. Coimbra: Almedina, 2012, v. 1.

. A posse: perspectivas dogmáticas actuais. 2. ed. Coimbra: Almedina, 1999.

Direitos reais. Sumários. Lisboa: AAFDL, 2000.

. Direitos reais. reimpressão da edição de 1979. Lisboa: Lex, 1993.

COSTA, José da Silva. Direito commercial maritimo. 2. ed. Paris: Société générale d'impression, 1912, t. 2.

COSTA, Mário Júlio de Almeida. Direito das obrigações. reimpr. da 7. ed. Coimbra: Almedina, 1999.

COUËTOUX, Henri. Droit romain : de la garantie dans la vente en cas d'éviction. Droit français : des achats et ventes de marchandises entre commerçants. Paris : A. Parent, 1874.

DE PAGE, Henri. Traité de droit civil belge: principes - doctrine - jurisprudence. Bruxelles : Établissements Émile Bruylant, 1934, t. 1, 2.

DECKER, Joseph de. Étude sur le droit de rétention. Bruxelles: Ferdinand Larcier, 1909.

DEL NERO, João Alberto Schützer. O significado jurídico da expressão "função social da propriedade". Revista da Faculdade de Direito de São Bernardo do Campo, São Bernardo do Campo, n. 3, p. 17-97, 1997.

DELGADO, José Augusto. A ética e a boa-fé no novo Código Civil. In: DELGADO, Mário Luiz; ALVES, Jones Figueirêdo. Questões controvertidas no novo código civil. São Paulo: Método, 2003, v. 1, p. 169-203.

DEMOLOMBE, Jean Charles Florent. Cours de code napoléon : Traité de la distinction des biens. Paris: Hachette, 1881, v. 9, t. 1.

DEMOGUE, René. Les notions fondamentales du droit privé : essai critique. Paris : Arthur Rousseau, 1911.

DERRIDA, Abraham-Albert-Roger. Recherches sur le fondement du droit de rétention. 1940. Tese de doutorado - Université d'Alger, Alger, 1940.

DIDIER JUNIOR, Fredie. Contribuição para o entendimento do art. 620 do CPC (cláusula geral de proteção contra o abuso do direito pelo exequente). Artigo disponível em $\mathrm{http}: / / \mathrm{www}$. frediedidier.com.br/wp-

content/uploads/2012/09/Contribui\%C3\%A7\%C3\%A3o-para-o-entendimento-doart.-620-do-CPC-cl\%C3\%A1 usula-geral-de-prote $\% \mathrm{C} 3 \% \mathrm{~A} 7 \% \mathrm{C} 3 \% \mathrm{~A} 30-$ contra-oabuso-do-direito-pelo-exequente $\% \mathrm{C} 2 \% \mathrm{~B} 9$.pdf, acessado pela última vez em 18.09.2015, às 11:52h.

. A função social da propriedade e a tutela processual da posse. Revista de processo, São Paulo, v. 33, n. 161, p. 9-20, jul. 2008.

DIDIER JUNIOR, Fredie; OLIVEIRA, Rafael. Execução e exceção de contrato não cumprido: notas ao art. 582 do CPC. Revista de Processo. São Paulo, v. 34, n. 172, p. 19-31, jun. 2009. 
DÍEZ-PICAZO, Luis. Fundamentos del derecho civil patrimonial: las relaciones obligatorias. 6. ed. Pamplona: Thomson Civitas, 2008, v.2.

DINIZ, Maria Helena. Curso de direito civil brasileiro. 25. ed. São Paulo: Saraiva, 2010, v. 4: Direito das coisas.

. As lacunas no direito. 6. ed. São Paulo: Saraiva, 2000.

. Lei de introdução ao código civil brasileiro interpretada: Lei de introdução às normas do direito brasileiro, de acordo com a Lei n. 12.376, de 30 de dezembro de 2010. 16. ed. São Paulo: Saraiva, 2011.

DOLINGER, Jacob. Direito internacional privado: parte geral. 9. ed. Rio de Janeiro: Renovar, 2008.

DUCLOS, José. L’opposabilité : essai d'une théorie générale. Paris : Librairie générale de droit et de jurisprudence, 1984.

DUGUIT, Léon. Les transformations générales du droit privé depuis le Code Napoléon. Paris: Félix Alcan, 1912.

- Manuel de droit constitutionnel : théorie générale de l'État - organisation politique. Paris : Albert Fontemoing, 1907.

DUPRAT, Deborah. Terras indígenas e o judiciário. Disponível em ttp://6ccr.pgr.mpf.mp.br/documentos-e-

publicacoes/artigos/docs_artigos/terras_indige nas_e_o_judiciario.pdf, acessado pela última vez em 19.08.2015, às 13:24h.

DUPREY, Louis. Du droit de rétention. Paris : F. Pichon, 1874.

DURANTON, Alexandre. Cours de droit civil français : suivant de Code civil. 3 ème ed. Paris: Alex-Gobelet, 1834, t. 18.

ELÉKES, André. De quelques différences dans l'application du droit de rétention d'après la jurisprudence française et allemande. Paris: Librairie générale de droit \& de jurisprudence, 1929.

ENGISCH, Karl. Introdução ao pensamento jurídico. 10. ed. traduzida. Lisboa: Fundação Calouste Gulbekian, 2008.

ESPÍNOLA, Eduardo. Garantia e extinção das obrigações: obrigações solidárias e indivisíveis. Rio de Janeiro: Freitas Bastos, 1951.

FACHIN, Luiz Edson. A função social da posse e a propriedade contemporânea: uma perspectiva da usucapião imobiliária rural. Porto Alegre: Sergio Antonio Fabris, 1988.

FACCHINI NETO, Eugênio. A função social do direito privado. Revista da AJURIS, Porto Alegre, v. 34, n. 105, p. 153-188, mar. 2007.

FARIAS, Cristiano Chaves de; ROSENVALD, Nelson. Direitos reais. 7. ed. Rio de Janeiro: Lumen Juris, 2011.

FERRARA, Francesco. Trattatto di diritto civile italiano. Roma: Athenaeum, 1921, v.1. 
FERRAZ JUNIOR, Tercio Sampaio. A demarcação de terras indígenas e seu fundamento constitucional. Revista brasileira de direito constitucional, São Paulo, n. 3, p.689-699, jan./jun. 2004.

. Introdução ao estudo do direito: técnica, decisão, dominação. 5. ed. São Paulo: Atlas, 2007.

FERREIRA, José G. do Valle. Enriquecimento sem causa. [S.1]: [S.N]., 1949.

FERRIÈRE, Claude de. Corps et compilation de tous les commentateurs anciens et modernes sur la Coutume de Paris : du Moulin, Charondas, Choppin, Tournet, Troncon, Guerin, Fortin, Brodeau, Ricard, Auzanet, \& autres. Paris : Denys Thierry et Augustin Besoigne, 1692, t. 2.

FIORE, Pasquale. Diritto internazionale privato: principii per risolvere i conflitti tra le leggi civili - commerciali - giudiziare - penali di stati diversi. 4. ed. Torino: Unione Tipografico-Editrice Torinense, 1904, v. 2.

FONSECA, Arnoldo Medeiros da. Direito de retenção. 3. ed. Rio de Janeiro: Revista Forense, 1957.

FRADA, Manuel A. Carneiro da. Contrato e deveres de proteção. Coimbra: Coimbra Editora, 1994.

FRANÇA, R. Limongi. Hermenêutica jurídica. 10. ed. São Paulo: Revista dos Tribunais, 2010.

FREITAS, Augusto Teixeira de. Consolidação das leis civis. edição fac-símile. Brasília: Senado Federal, 2003, v. 1.

FREITAS, José Lebre de. A transmissão do direito à indemnização por benfeitorias e a caducidade do direito de retenção pelo facto da venda executiva. THEMIS Revista da Faculdade de Direito da Universidade Nova de Lisboa, Lisboa, ano VII, n. 13, p. 5-29, 2006.

FRONTINI, Paulo Salvador. Seção VIII: Dos efeitos da decretação da falência sobre as obrigações do devedor. In: SOUZA JUNIOR, Francisco Satiro de; PITOMBO, Antônio Sérgio A. de Moraes. Comentários à lei de recuperação de empresas e falência: Lei 11.101/2005. São Paulo: Revista dos Tribunais, 2007, p. 434-468.

FULGÊNCIO, Tito. Da posse e das ações possessórias. 10. ed. Rio de Janeiro: Forense, 2008.

GALLO, Paolo. L'arricchimento senza causa. Padova: CEDAM - Casa Editriche Dott. Antonio Milani, 1990.

GARBASSO, Carlo-Luigi. Il diritto di ritenzione ed il precario nella legislazione italiana. Torino: San Giuseppe, 1883.

GARNOT, Paul. De l'effet des exceptions partielles en droit romain classique. Des obligations hypothécaires au porteur en droit français. Lyon : Association Typographique, 1894.

GAROFALO, Luigi. Per un'applicazione dell'exceptio doli generalis romana in tema di contratto autonomo di garanzia. Rivista di diritto civile, Padova, v. 42, n. 5, p.629661, sett./ott. 1996. 
GARRAUD, René. Du droit de rétention. Paris : F. Pichon, 1874.

GAUDEMET, Jean. Institutions de l'Antiquité. Paris: Sirey, 1967.

GAUTIER, Alfred. Précis de l'histoire du droit français. 3. ed. Paris: L. Larose et Forcel, 1887.

GAULTIER, C. Du droit de rétention. Paris: V. Giard et E. Brière, 1898.

GILISSEN, John. Introdução histórica ao direito. 5. ed. Lisboa: Fundação Calouste Gulbekian, 2008.

GIORGI, Jorge. Teoría de las obligaciones en el derecho moderno: expuesta conforme a la doctrina y la jurisprudencia italiana, francesa, alemana, etc., etc. Madrid: Reus, 1928, v. 2, traduzido da $7^{\mathrm{a}}$ edição italiana.

GIRARD, Paul Frédéric. Manuel élémentaire de droit romain. 5. ed. Paris : Arthur Rousseau, 1911.

GISLAIN, Ferdinand. Des impenses et du droit de rétention. Bruxelles : A. Labroue, 1854.

GLASSON, Ernest-Désiré. Du droit d'accroissement entre co-héritiers et entre colégataires en droit romain. Du droit de rétention sous l'empire du Code Napoléon. Paris : A. A. Durand, 1862, $2^{\mathrm{a}}$ parte.

GODOY, Claudio Luiz Bueno de. Função social do contrato. 4. ed. São Paulo: Saraiva, 2012.

. Código civil e código de defesa do consumidor: convergência de princípios e distinção de sua modulação. Um paralelo entre os deveres que criam. In: MELGARÉ, Plínio. O direito das obrigações na contemporaneidade: estudos em homenagem ao ministro Ruy Rosado de Aguiar Júnior. Porto Alegre: Livraria do Advogado, 2014, p. 109-134.

GOMES, Júlio. Do direito de retenção (arcaico, mas eficaz...). Cadernos de direito privado, Braga, n. 11, p. 3-25, jul./set. 2005.

GOMES, Júlio Manuel Vieira. O conceito de enriquecimento, o enriquecimento forçado e os vários paradigmas do enriquecimento sem causa. Porto: Universidade Católica Portuguesa, 1998.

GOMES, Mário A. Magalhães. Do direito de retenção no codigo civil brasileiro: doutrina, jurisprudencia e pratica. São Paulo: Saraiva, 1931

GOMES, Orlando. Direitos Reais. 20. ed. Rio de Janeiro: Forense, 2010.

. Contratos. 26. ed. Rio de Janeiro: Forense, 2008.

GÓMEZ CALLE, Esther. El derecho de retención sobre bienes muebles. InDret: Revista para es análisis del derecho. Barcelona, n. 4, p. 5-88, out./2011. Disponível em http://www.indret.com/pdf/858_es_.pdf, acessado pela última vez em 03.11.2015, às $16 \mathrm{~h} 00$.

GONÇALVES, Carlos Roberto. Direito civil brasileiro. 7. ed. São Paulo: Saraiva, 2012, v. 5: Direito das Coisas. 
GORÉ, François. L'enrichissement aux dépens d'autrui : source autonome et générale d'obligations en droit privé français. Paris : Dalloz, 1949.

GRANDMOULIN, J. Traité élémentaire de droit civil égyptien indigène et mixte comparé avec le droit français : conforme aux programmes de l'École khédiviale et des facultés françaises de droit. Rennes: Thanoux, 1912.

GUARRACINO, Alessandro. Il diritto di ritenzione nella legislazione italiana. Napoli: Gennaro de Angelis e Figlio, 1884.

GUÉTAT, Édouard. Du droit de rétention. Concours pour l'agrégation des Facultés de Droit. Paris : imp. de Ghémar, 1874.

GUIGOU, Gabriel-Just. Des obligations naturelles en droit romain et en droit français. Marseille: Imprimerie Marseillaise, 1893.

GUILLOUARD, Louis-Vincent. Traités du nantissement et du droit de rétention : livre III, titre XVII du Code Civil. Paris: Durand et Pedone-Lauriel, 1895.

GUNE, Boaventura; ALVES, Sílvia; RODRIGUES, Luís Barbosa. Código civil e legislação complementar de Moçambique. Coimbra: Almedina, 2006.

HÉDAL, Paul-Émile-Marie. Du droit de rétention. Rennes : Imprimerie du commerce Bazouge fils et cie., 1874.

HEREDIA DE ONIS, Pablo Beltran de. El derecho de retención en el Código civil español. Salamanca: Universidad de Salamanca, 1955.

HEURTEY, Octave. De pignoribus et hypothecis. Du droit de rétention. Paris : Charles de Mourgues frères, 1859.

HIRONAKA, Giselda Maria Fernandes Novaes. A função social do contrato. Revista de Direito Civil, Imobiliário, Agrário e Empresarial, São Paulo, v. 12, n. 45, p. 141-151, jul./set. 1988.

JABUR, Alexandre. A indenização da terra nua nas demarcações de terras indígenas: modelos e teses em discussão. 2014. Tese de conclusão do $26^{\circ}$ Concurso de Ingresso e Vitaliciamento - Escola Superior do Ministério Público da União, Manaus, 2014. Disponível em http://6ccr.pgr.mpf.mp.br/institucional/grupos-detrabalho/gt-demarcacao/doc_artigos/alexandre-jabur, acessado pla última vez em 19.08.2015, às 12:34h.

JHERING, Rudolf Von. A finalidade do direito. Campinas: Bookseller, 2002.

JONESCO, César. Du droit de rétention. Paris : V. Giard et E. Brière, 1908.

JOSSERAND, Louis. De l'esprit des droits et de leur relativité : théorie dite de l'abus des droits. 2ème ed. Paris : Dalloz, 1939.

Del abuso de los derechos y otros ensayos. Santa Fé de Bogotá: Temis, 1999.

KHOURI, Paulo R. Roque A. A exceção do contrato não cumprido e a sua relação com a garantia das obrigações no direito brasileiro. Revista da Ajuris, Porto Alegre, v. 31, n. 94, p. 293-317, jun. 2004.

LAFARGUE, Fernand. De la revendication en droit romain: théorie du droit de rétention en droit français. Bordeaux: A. Bellier, 1881. 
LARANJEIRA, Raymundo. A ocupação das terras indígenas pelos posseiros de boa fé e o direito a indenização por benfeitorias. In: SANTILLI, Juliana [coord.]. Os direitos indígenas e a constituição. Porto Alegre: Núcleo de Direitos Indígenas e Sergio Antonio Fabris, 1993, p. 81-143.

LAURENT, F. Principes de droit civil français. 3ème ed. Paris: A. Maresq, 1878, t. 29.

Le droit civil international. Paris : A. Marescq, Ainé, 1881, t. 7.

LEGRAND, Charles. Du droit de rétention. Paris : Arthur Rousseau, 1906.

LEITÃO, Luís Manuel Teles de Menezes. O enriquecimento sem causa no direito civil: estudo dogmático sobre a viabilidade da configuração unitária do instituto, face à contraposição entre as diferentes categorias de enriquecimento sem causa. Coimbra: Almedina, 2005.

. O enriquecimento sem causa no novo código civil brasileiro. Revista CEJ, Brasília, v. 8, n. 25, p. 24-33, abr./jun. 2004.

. Direitos reais. 3. ed. Coimbra: Almedina, 2012.

LEIVA FERNÁNDEZ, Luis F. P. Derecho de retención: Caracterización. Efectos. Requisitos. Teoría general. Retención irregular o anómala. Faculdade de retención y derecho penal. Buenos Aires: Astrea, 1991.

LIMA, Alvino Ferreira. O direito de retenção e o possuidor de má fé. 2. ed. São Paulo: Lejus, 1995.

LIMA, Pires de; VARELA, Antunes. Código civil anotado. 4. ed. Coimbra: Coimbra Editora, 1987, v. 1.

LOPES, João Batista. Ação declaratória. 6. ed. São Paulo: Revista dos Tribunais, 2009.

LOPES, José Reinaldo Lima. 6. Direito subjetivo e direitos sociais: o dilema do Judiciário no Estado social de Direito. In: FARIA, José Eduardo [org.]. Direitos humanos, direitos sociais e justiça. 2. tiragem da 1. ed. São Paulo: Malheiros, 1998, p. 113143.

LOPES, Miguel Maria de Serpa. Exceções substanciais: exceção de contrato não cumprido (exceptio non adimpleti contractus). Rio de Janeiro: Freitas Bastos, 1959.

Curso de direito civil. 4. ed. Rio de Janeiro: Freitas Bastos, 1964, v. 3: Fontes das Obrigações, Contratos.

Comentários à lei de introdução ao código civil. 2. ed. Rio de Janeiro: Freitas Bastos, 1959, v. 2.

LOPEZ, Teresa Ancona. Comentários ao Código Civil: Parte Especial - Das várias espécies de contratos; (Artigos 565 a 652). São Paulo: Saraiva, 2003, v. 7 (Comentários ao Código Civil).

LÓPEZ DE HARO, Carlos. EI derecho de retención. Madrid: Reus, 1921.

LOUREIRO, Francisco Eduardo. A propriedade como relação jurídica complexa. Rio de Janeiro: Renovar, 2003.

Art. 1.228. In: PELUSO, Cezar [coord.]. Código civil comentado: doutrina e jurisprudência. 2. ed. São Paulo: Manole, 2008, p. 1144-1155. 
LOUREIRO, Luiz Guilherme. Direitos reais: à luz do código civil e do direito registral. São Paulo: Método, 2004.

LUMIA, Giuseppe. Principios de teoria e ideologia del derecho. Madrid: Debate, 1973.

MADALENO, Cláudia. A vulnerabilidade das garantias reais: a hipoteca voluntária face ao direito de retenção e ao direito de arrendamento. Coimbra: Coimbra editora, 2008.

MARAIS, Georges. De la condition juridique du constructeur de navires. Revue de droit maritime comparé, Paris, t. 14, p. 1-25, Juillet-décembre 1926.

MARINO, Francisco Paulo De Crescenzo. Classificação dos contratos. In: JABUR, Gilberto Haddad; PEREIRA JUNIOR, Antonio Jorge [coord.]. Direito dos contratos. São Paulo: Quartier Latin, 2006, p. 22-50.

MARINONI, Luiz Guilherme; MITIDIERO, Daniel. Código de processo civil comentado: artigo por artigo. 3. ed. São Paulo: Revista dos Tribunais, 2011.

MARINONI, Luiz Guilherme; ARENHART, Sérgio Cruz. Curso de processo civil: processo de conhecimento. 6. ed. São Paulo: Revista dos Tribunais, 2007, v. 2.

Execução. 4. ed. 2. tiragem. São Paulo: Revista dos Tribunais, 2012.

MARMOL, Charley Del. Quelques aspects du droit de rétention, spécialement dans l'industrie lainière. Paris : Rousseau et Cie, 1934.

MARQUES, António Vicente. Código civil angolano. 1. ed. Luanda: Texto Editores, 2006.

MARQUES, Claudia Lima. Contratos no Código de Defesa do Consumidor: o novo regime das relações contratuais. 5. ed. São Paulo: Revista dos Tribunais, 2005.

MARTINEZ, Pedro Romano; DA PONTE, Pedro Fuzeta. Garantias de cumprimento. 5. ed. Coimbra: Almedina, 2006.

MARTINS-COSTA, Judith. A boa-fé no direito privado. São Paulo: Revista dos Tribunais, 1999.

. Reflexões sobre o princípio da função social dos contratos. Revista Brasileira de Direito Comparado, Rio de Janeiro, n. 29, p. 65-102, 2005.

MASNATTA, Hector. Excepción de incumplimiento contractual. [Buenos Aires]: Abeledo-Perrot, [1967].

MASSIUS. Le droit de rétention des réparateurs d'automobiles. Paris: Blanchard, Chambre nationale de la carrosserie, 1938.

MASSOL, Henri. De l'obligation naturelle et de l'obligation morale en droit romain et en droit français. 2ème ed. Paris: Auguste Durand, 1862.

MATHIAS, Maria Ligia Coelho. Direito civil : direitos reais. reimpressão da 1. ed. São Paulo : Atlas, 2006.

MAUGER, Charles. De la nature du droit de rétention. Paris : A. Chevalier-Marescq, 1900. 
MAY, Gaston. Éléments de droit romain : à l'usage des étudiants des Facultés de droit. 7ème ed. Paris : L. Larose, 1901.

MAZELIÉ, Jules. Du droit de rétention en droit romain et en droit français. Toulouse: Typographie de Bonnal et Gibrac, 1868.

. Étude sur le droit de rétention en droit romain et en droit français. Toulouse: Frerrère, 1868.

MENDES, Gilmar Ferreira. O domínio da União sobre as terras indígenas: o Parque Nacional do Xingu. Brasília: Ministério Público Federal, 1988.

MENDES JUNIOR, João. Os indígenas do Brazil, seus direitos individuaes e políticos. São Paulo: Typ. Hennies Irmãos, 1912.

MENDONÇA, José Xavier Carvalho de. Tratado de direito commercial brasileiro. 3. ed. Rio de Janeiro: Freitas Bastos, 1952, v. 8.

MESSINEO, Francesco. Il contrato in genere. Milano: Dott. A. Giuffrè, 1973, t. 1.

MIHILLS, Lee Knowlton. A summary of the commercial law of the United States: with business forms and practical suggestions, 1889, p. 358-361. Disponível em: http://heinonline.org, acessado em 26.10.2015, às 13h10.

MIRANDA, Francisco Cavalcanti Pontes de. Tratado de direito privado. 4. ed. São Paulo: Revista dos Tribunais, 1974, t. 6.

. Tratado de direito privado. Rio de Janeiro: Borsoi, 1955, t. 10: Direito das Coisas, Posse.

. Tratado de direito privado. Rio de Janeiro: Borsoi, 1954, t. 3.

. Tratado de direito privado. 4. ed. São Paulo: Revista dos Tribunais, 1974, t. 2 : Parte geral.

- Tratado de direito privado. São Paulo: Revista dos Tribunais, 2012, t. 11: Direito das coisas.

MONTESSORI, Roberto. Il diritto di ritenzione nella materia commerciale. Milano: Francesco Vallardi, [1908].

MOREIRA, Álvaro; FRAGA, Carlos. Direitos reais. Coimbra: Almedina, 1972.

MORSELlO, Marco Fábio. Contratos existenciais e de lucro. Análise sob a ótica dos princípios contratuais contemporâneos. In: LOTUFO; NANNI; MARTINS [coord.]. Temas relevantes do direito civil contemporâneo: reflexões sobre os 10 anos do Código Civil. São Paulo: Atlas, 2012, p. 292-307.

- Direito civil constitucional e o direito de propriedade no Brasil e no direito comparado. Revista da Pós-Graduação da Faculdade de Direito da USP, Porto Alegre, v. 2, p. 93-125, 2000.

. Da boa-fé nas fases pré e pós-contratuais no direito brasileiro. In: JABUR, Gilberto Haddad; PEREIRA JUNIOR, Antonio Jorge [coord.]. Direito dos contratos II. São Paulo: Quartier Latin, 2008, p. 295-310. 
MOURLON, Frédéric. Répétitions écrites sur le troisième examen du Code Napoléon: contenant l'exposé des principes généraux, leurs motifs et la solution des questions théoriques. 9ème ed. Paris: Marescq Ainé, 1874, t. 3.

NADER, Paulo. Introdução ao estudo do direito. 24. ed. Rio de Janeiro: Forense, 2004.

NANNI, Giovanni Ettore. Abuso do Direito. In: LOTUFO; NANNI [coords.]. Teoria geral do direito civil. São Paulo: Atlas, 2008, p. 738-772.

- Contratos coligados. In: LOTUFO; NANNI [coords.]. Teoria geral dos contratos. São Paulo: Atlas, 2011, p. 224-294.

. Mora. In: LOTUFO; NANNI [coords.]. Obrigações. São Paulo: Atlas, 2001, p. 571-652.

Enriquecimento sem causa. 3. ed. São Paulo: Saraiva, 2012.

NEGRÃO, Ricardo. Manual de direito comercial e de empresa. 5. ed. São Paulo: Saraiva, 2010, v. 3.

NEVES, Daniel Amorim Assumpção. Manual de direito processual civil. São Paulo: Método, 2009.

NIBOYET, J.-P. La notion de réciprocité dans les traités diplomatiques de droit international privé. In : ACADÉMIE DE DROIT INTERNATIONAL DE LA HAYE. Recueil des cours. Paris : Sirey, 1935 - II, t. 52, p. 256-361.

NICOLAS, R. Étude sur le droit de rétention légal à Rome et en France. Paris: Pichon et Cie, 1872.

NONATO, Orosimbo. Curso de obrigações: generalidades - espécies. Rio de Janeiro: Forense, 1959, v.1.

NORONHA, Fernando. Direito das obrigações. 3. ed. São Paulo: Saraiva, 2010.

NUYTS, Arnaud. Le droit de rétention en droit international privé : quelques observations sur le rôle de la loi de l'obligation, de la loi réelle, et de la loi di lieu d'exécution. Revue générale de droit civil belge, n.1992/1, p. 30-54, jan./fev. 1992. Disponível em http://www.dipulb.be/fileadmin/user_files/arnauddroitretentionrgdc.pdf, acessado pela última vez em 12.11.2015, às 10:14h.

OFFIDANI, Alessandro Mariano. Contributo ala teoria dela posizione giuridica. Torino: G. Giappichelli, 1952.

PACHECO, Antonio Faria Carneiro. Do direito de retenção. Rio de Janeiro: Jacintho Ribeiro dos Santos, 1912.

PARDESSUS, J. M. Table chronologique des ordonnances des rois de France de la troisième race: jusqu'au régne de Louis XII inclusivement. Paris: imprimerir royale, 1847.

PASQUALOTTO, Adalberto. A boa-fé nas obrigações civis. In: MEDEIROS, Antonio Paulo Cachapuz de [coord.]. Faculdade de Direito da PUCRS: o ensino jurídico no limiar do novo século. Porto Alegre, EDIPUCRS, 1997, p. 109-136.

PENTEADO, Luciano de Camargo. Direito das coisas. São Paulo: Revista dos Tribunais, 2008. 
Efeitos contratuais perante terceiros. São Paulo: Quartier Latin, 2007.

PEREIRA, Caio Mário da Silva. Instituições de direito civil. 18. ed. Rio de Janeiro: Forense, 2004, v. 4: direitos reais.

PEREIRA, Lafayette Rodrigues. Direito das Coisas. 6. ed. Rio de Janeiro: Freitas Bastos, 1956.

. Direito das coisas. Brasília: Senado Federal, Superior Tribunal de Justiça, 2004, v. 1.

PERSICO, Giovani. L'eccezione d'inademplimento. Milano: Giuffrè, 1955.

PIERRON, Alfred. Des droits du vendeur non payé en droit romain. De la rétention, de la revendication et du privilège du vendeur en droit français. Poitiers : Imprimerie E. Wirquin, 1874.

PINHEIRO, Luís de Lima. Direito internacional privado. 2. reimpressão. Coimbra: Almedina, 2005, $2 \mathrm{v}$.

PINOT, Pierre. Essai d'une théorie du droit de rétention au point de vue législatif. Paris : F. Pichon et Durand-Auzias, 1908.

PITTI-FERRANDI, Sylvestre-Joseph-Marie de. Du droit de rétention. Paris : F. Pichon, 1874.

PLANIOL, Marcel. Traité élémentaire de droit civil: conforme au programme officiel des facultés de droit. 10e ed. Paris: R. Pichon et R. Durand-Auzias, 1926-1928, t. 1 e 2 .

PLANIOL, Marcel; RIPERT, Georges; ESMEIN, Paul. Traité pratique de droit civil français. Paris: R. Pichon et R. Durand-Auzias, 1952, v. 2.

POGONATO, Pierre. Droit de rétention. Paris : L. Larose et L. Tenin, 1909.

PONTES, Tito Lívio. Da Posse: prática, doutrina, jurisprudência, legislação. 2. ed. São Paulo: Livraria e Editora Universitária de Direito: 1977.

POPESCO, Georges-Iorgu D. Le droit de rétention en droit anglais ("lien”) : avec des aperçus comparatifs sur les mêmes institutions juridiques correspondantes en droit français, en droit allemand et en droit suisse. Paris: Arthur Rousseau, 1930.

PRÉCIS de droit civil. 5ème ed. Paris : Dalloz, 1936, t. 2.

PRET, Célestin-Aimé. Le droit de rétention dans les législations anciennes et modernes française et étrangères. Paris: Ernest Thorin, 1881.

PÚPERI, Cyro Luiz Pestana. A função social, econômica e a preservação do meio ambiente como condições limitadoras do direito de propriedade. Revista da AJURIS, Porto Alegre, v. 34, n. 105, p. 91-134, mar. 2007.

RAMOS, André de Carvalho. Curso de direitos humanos. 2. ed. São Paulo: Saraiva, 2015.

. Direito internacional privado de matriz legal e sua evolução no Brasil. Revista da AJURIS, Porto Alegre, v. 42, n. 137, p. 89-113, mar. 2015. 
- Evolução histórica do direito internacional privado e a consagração do conflitualismo. Revísta de la Secretaría del Tribunal Permanente de Revisión, Asunción, año 3, n. 5, p. 423-446, mar. 2015.

RAMPONI, Lamberto. Il diritto de ritenzione nelle leggi italiane. Firenze: Luigi Niccolai, 1898, v.1.

RAMSAY, Thomas Kennedy. Notes sur la Coutume de Paris : indiquant les articles en force avec tout le texte La Coutume à l'exception des articles relatifs aux fiefs et censives les titres du retrait lignager et de la garde noble et bourgeoise. Montréal : Minerve, 1863.

REALE, Miguel. História do novo código civil. São Paulo: Revista dos Tribunais, 2005.

. O sentido inovador do projeto do novo código civil (exposição e debate). Revista Forense Comemorativa 100 anos, Rio de Janeiro, edição comemorativa, t. III, p. 735-766.

. O projeto do novo Código Civil: situação após a aprovação pelo Senado Federal. 2. ed. São Paulo: Saraiva, 1999.

Lições preliminares de direito. 27. ed, 8. tiragem. São Paulo: Saraiva, 2009.

REALE JUNIOR, Miguel. Função social do contrato: integração das normas do capítulo $\mathrm{XV}$ com os princípios e as cláusulas gerais. In: FÓRUM DE DIREITO DO SEGURO. Fórum de Direito do Seguro José Sollero Filho. São Paulo: IBDS; EMTS, 2003, p. 35-56.

RIBEIRO, Darci Guimarães. Perspectivas epistemológicas do direito subjetivo. Revista da AJURIS, Porto Alegre, v. 38, n. 121, p. 119-145, mar. 2011.

RICCA-BARBERIS, Mario. Spese utili, miglioramenti, innovazioni, piantagioni ed edifici in comune. Torino: G. Giappichelli, 1946.

RICHARD, Ernest. De l'obligation naturelle en droit romain et en droit français. Lyon: Imprimerie de P. Mougin-Rusand, 1872.

RÍOS LABBÉ, Sebastián. La reforma del derecho de garantías en Francia. Puesta al día necesaria y fracaso parcial de una reforma de conjunto. Revista chilena de derecho privado Fernando Fueyo Laneri. Santiago de Chile, n. 7, p. 89-116, diciembre/2006.

ROCCO, Alfredo. Princípios de direito comercial: parte geral. São Paulo: Saraiva, 1934.

RODAS, João Grandino. Elementos de conexão do direito internacional privado brasileiro relativamente às obrigações contratuais. In: RODAS, João Grandino [coord.]. Contratos internacionais. 3. ed. São Paulo: Revista dos Tribunais, 2002, p. 19-65.

RODRIGUES, Manuel. A posse: estudo de direito civil português. 3. ed. Coimbra: Almedina, 1980.

RODRIGUES, Silvio. Direito civil. 28. ed. São Paulo: Saraiva, 2006, v. 5: Direito das coisas.

. Direito Civil. 29. ed. São Paulo, Saraiva, 2003, v. 3: Dos contratos e das declarações unilaterais de vontade. 
Direito Civil. 34. ed. São Paulo, Saraiva, 2003, v. 1: Parte Geral.

ROME, Jules. De l'action paulienne en droit romain et en droit français. Paris : Retaux Frères, 1866.

RONY, Louis. Du droit de rétention en droit romain et en droit français. Paris : Imprimerie de Moquet, 1867.

ROPPO, Enzo. O contrato. Coimbra: Almedina, 2009.

ROSS, Alf. Tû-tû. São Paulo: Quartier Latin, 2004.

. Sobre el derecho y la justicia. Buenos Aires: Editorial Universitaria de Buenos Aires, 1977.

RUGGIERO, Biasi. Das benfeitorias - art. 35. In: OLIVEIRA, Juarez de [coord.]. Comentários à lei de locação de imóveis urbanos: Lei n. 8.245, de 18 de outubro de 1991. São Paulo: Saraiva, 1992, p. 259-265.

RUGGIERO, Roberto de. Instituições de direito civil. 3. ed. São Paulo: Saraiva, 1973, v. 3.

SACCO, Rodolfo. L'arricchimeto ottenuto mediante fato ingiusto: contributo ala teoria dela responsabilità estracontrattuale. Torino: Unione tipografico-editrice torinense, 1959.

SACCO, Rodolfo; NOVA, Giorgio de. Il contrato. $3^{\text {a }}$ ed. Torino: UTET, 2004, t. 2.

SAINT-BONNET, M. Nouveau dictionnaire de droit français : à l'usage de tout le monde. 2. tiragem. Paris : A. Durand et Pedone Lauriel, 1872.

SANTOS, Francisco Cláudio de Almeida. Direito do promitente comprador e direitos reais de garantia: penhor - hipoteca - anticrese. São Paulo: Revista dos Tribunais, 2006.

SARBASH, Sergei V. The right of retention in new Russian legislation. Review of Central and East European law. n. 3/4, p. 241-266, 1997.

SAVIGNY, Friedrich Karl von. Traité de droit romain. traduzido do alemão. Paris : Firmin Didot frères, 1855, t. 1.

SENADO FEDERAL. Código Civil: anteprojetos. Brasília: Senado Federal, 1989, 5 v.

SERAU JUNIOR, Marco Aurélio. A função social no Código Civil - Aspectos da publicização do Direito Privado. Revista Forense, Rio de Janeiro, v. 100, n. 375, p. 103-139, set./out. 2004.

SERVIN, Louis. Du gage en droit romain et en droit français. Paris : F. Pichon, 1875.

SIAN, David C. G. Some aspects of the possessory lien in actions in rem. Malaya Law Review, n. 326, p. 312-26, 1988.

SILVA, Jorge Cesa Ferreira da. A boa-fé e a violação positiva do contrato. Rio de Janeiro: Renovar, 2002.

SILVA, José Afonso da. Terras tradicionalmente ocupadas pelos índios. In: SANTILLI, Juliana [coord.]. Os direitos indígenas e a constituição. Porto Alegre: Núcleo de Direitos Indígenas e Sergio Antonio Fabris, 1993, p. 45-50. 
. Auto-aplicabilidade do artigo 198 da Constituição Federal. Revista Trimestral de Jurisprudência dos Estados, São Paulo, v. 7, n. 25, p. 3-13, out./dez. 1983.

SILVA, Paulo Thadeu Gomes da. Os direitos dos índios: fundamentalidade, paradoxos e colonialidades internas. São Paulo: Café com lei, 2015.

SIMÃO, José Fernando. Direito civil: contratos. 5. ed. São Paulo: Atlas, 2011.

Prescrição e decadência: início dos prazos. São Paulo: Atlas, 2013

SIQUEIRA, Cleante Guimarães. A defesa no processo civil: as exceções substanciais no processo de conhecimento. 3. ed. São Paulo: Saraiva, 2008.

SOUZA, Silma Marlice Zorub. Ensaio sobre direito subjetivo e situação jurídica. 1978. Dissertação de mestrado - FDUSP. São Paulo, 1978.

STRENGER, Irineu. Direito internacional privado. 3. ed. São Paulo: LTr, 1996.

. Lacunas da lei em direito internacional privado. Revista do direito do comércio e das relações internacionais, São Paulo, v. 1, n. 1, p. 129-143, 1989

TARTUCE, Flávio. Função social dos contratos: do Código de Defesa do Consumidor ao Código Civil de 2002. São Paulo: Método, 2007.

Manual de direito civil: volume único. São Paulo: Método, 2011.

- A revisão do contrato pelo novo Código Civil. Crítica e proposta de alteração do art. 317 da Lei 10.406/02. In: DELGADO, Mário Luiz; ALVES, Jones Figueirêdo. Questões controvertidas no novo código civil. São Paulo: Método, 2003, v. 1, p. $125-148$.

. Questões polêmicas quanto ao direito das coisas no novo Código Civil. Visão crítica sobre a nova codificação. In: BARROSO, Lucas Abreu [org.]. Introdução crítica ao Código Civil. Rio de Janeiro: Forense, 2006, p. 362-381.

TARTUCE, Flávio; SIMÃO, José Fernando. Direito civil. 4. ed. São Paulo: Método, 2012, v. 4: Direito das Coisas.

TEPEDINO, Gustavo. Temas de direito civil. Rio de Janeiro: Renovar, 2006, t. 2.

THEODORO JÚNIOR, Humberto. Processo de execução. 19. ed. São Paulo: Livraria e Editora Universitária de Direito, 1999.

. Posse e propriedade: jurisprudência. São Paulo: Livraria e Editora Universitária de Direito, 1985.

TOMMASINI, Alessandra. La specialità della ritenzione agraria: tra iniziativa privata e programmi di intervento pubblico. Milano: Dott. A. Giuffrè Editore, 2006.

TORRENTE, Andrea. Manuale di diritto privato. 9a ed. Milano: A. Giuffrè, 1975.

TOURINHO NETO, Fernando da Costa. Os direitos originários dos índios sobre as terras que ocupam e suas consequências jurídicas. In: SANTILLI, Juliana [coord.]. Os direitos indígenas e a constituição. Porto Alegre: Núcleo de Direitos Indígenas e Sergio Antonio Fabris, 1993, p. 9-43.

TUCCI, Rogério Lauria; AZEVEDO, Álvaro Villaça. Tratado de locação predial urbana. São Paulo: Saraiva, 1980, v. 1. 
VACHEZ, Antoine. Du droit de rétention. Paris : Imprimerie de Moquet, 1860.

VALLADÃO, Haroldo. História do direito especialmente do direito brasileiro. Rio de Janeiro: Freitas Bastos, 1973, v. II: Direito brasileiro imperial e republicano.

VALLIMARESCO, Alexandre. La justice privée en droit moderne. Paris : Edouard Duchemin, L. Chauny et L. Quinsac, 1926.

VAN WETTER, Polynice Alfred Henri. Cours élémentaire de droit romain : contenant la législation de Justinien avec l'histoire tant externe qu'interne du droit romain. Paris: A. Durand et Pedone-Lauriel, 1871, t. 1.

VARELA, João de Matos Antunes. Das obrigações em geral. 6. reimp. 10. ed. Coimbra: Almedina, 2009, v. 1.

. Das obrigações em geral. 4. reimpr. 7. ed. Coimbra: Almedina, 2009, vol. 2.

VASCONCELOS, Ronaldo. Eficácia executiva das sentenças declaratórias no CPC (Lei n. 11.232/2005) in COSTA, Susana Henriques da [coord.]. A Nova Execução CivilLei 11.232/05. São Paulo: Quartier Latin, 2006, p. 96-110.

VASCONCELOS, L. Miguel Pestana de. Direito das garantias. Coimbra: Almedina, 2010.

VENEGAS RODRÍGUEZ, Rubén. El derecho de retención: doctrina, legislación comparada, jurisprudencia. Santiago: Editorial Nascimento, 1940.

VENOSA, Silvio de Salvo. Direito civil. 11. ed. São Paulo: Atlas, 2011, v. 5: direitos reais.

VERNIS, Eugène. Du droit de suite par hypothèque en droit romain et en droit français. Dijon : F. Carré, 1884.

VILLARES, Luiz Fernando. Direito e povos indígenas. Curitiba: Juruá, 2009.

VIVANTE, Cesare. Trattato di diritto commerciale. Torino : Fratelli Bocca, 1896, v. 2, parte 2 .

WALD, Arnoldo. Curso de direito civil brasileiro. 9. ed. São Paulo: Revista dos Tribunais, 1993, v. 3: Direito das Coisas.

. Direito das coisas. 11. ed. São Paulo : Saraiva, 2002.

WAMBIER, Teresa Arruda Alvim. Uma reflexão sobre as "cláusulas gerais" do código civil de 2002: a função social do contrato. Revista dos Tribunais, São Paulo, v. 94, n. 831, p. 59-79, jan. 2005.

ZANETTI, Cristiano de Souza. Responsabilidade pela ruptura das negociações. São Paulo: Juarez de Oliveira, 2005.

ZARA, Laurent G. Du droit de rétention. Paris: Arthur Rousseau, 1902.

ZAVASCKI, Teori Albino. A tutela da posse na constituição e no projeto de novo código civil. In: MARTINS-COSTA, Judith. A reconstrução do direito privado: reflexos dos princípios, diretrizes e direitos fundamentais constitucionais no direito privado. São Paulo: Revista dos Tribunais, 2002, p. 843-861. 


\section{DiCIONÁRIOS}

AULETE, Francisco Julio Caldas. Dicionário contemporâneo da língua portuguêsa. 3. ed. Lisboa: Delta, 1978, v. 2 p. 797. HOUAISS, Antonio.

BLACK'S Law Dictionary. Abridged Eighth Edition. St. Paul: West Publishong Company, 2005.

VILLAR, Mauro de Salles. Dicionário Houaiss de língua portuguesa. Rio de Janeiro: Objetiva, 2001.

\section{INTERNET}

CÓDIGO CIVIL ITALIANO. Disponível em http://www.diritto.it/codici/1, acessado pela última vez em 27/09/2015, às 08h57.

CÓDIGO CIVIL ESPANHOL. Disponível em http://www.boe.es/buscar/act.php?id=BOEA-1889-4763, em 27/09/2015, às 18h46.

CÓDIGO CIVIL BELGA. Disponível em http://www.droitbelge.be/codes.asp\#civ, consultado em 27/09/2015, às $10 \mathrm{~h} 05$.

LEGISLAÇÃO DE LUXEMBURGO. Disponível em http://www.legilux.public.lu/leg/textescoordonnes/codes/code_civil/CodeCivil_Pag e Accueil.pdf, visto em 30/09/2015, às 13 h56.

LEGISLAÇÃO DE MÔNACO. Disponível em http://www.legimonaco.mc/305/legismclois.nsf/ViewSommaire/8a6b5046e820019 9c 12574fd00485cc8! OpenDocument\#, acessado em 27/09/2015, às 19h21.

CÓDIGO CIVIL URUGUAIO. Disponível em http://www.parlamento.gub.uy/codigos/codigocivil/2002/cod_civil.htm, acessado em 27/09/2015, às $11 \mathrm{~h} 15$.

LEGISLAÇÃO CHILENA. Disponível em http://www.leychile.cl/Navegar?idNorma=172986, consultado pela última vez em $27 / 09 / 2015$, às $15 \mathrm{~h} 23$.

LEGISLAÇÃO COLOMBIANA. Disponível em http://www.alcaldiabogota.gov.co/sisjur/normas/Norma1.jsp?i=39535, consultado em 26/09/2015, às $21 \mathrm{~h} 30$.

LEGISLAÇÃO BOLIVIANA. Disponível em http://silep.vicepresidencia.gob.bo/SILEP/masterley/118561, acessado pela última vez em 27/09/2015, às 14h31.

LEGISLAÇÃO VENEZUELANA. Disponível em http://www.mp.gob.ve/LEYES/codigo\%20civil/codigo\%20civil.html, acessado pela última vez em 27/09/2015, às 13 h12. 
LEGISLAÇÃO DA NICARAGUA. Disponível em http://www.oas.org/dil/esp/Codigo_Civil_Nicaragua.pdf, em 27/09/2015, às 12h10.

CÓDIGO CIVIL DE EL SALVADOR. Disponível em em https://www.oas.org/dil/esp/Codigo_Civil_El_Salvador.pdf, em 30/09/2015, às $12 \mathrm{~h} 15$.

LEGISLAÇÃO

MEXICANA.

Disponível

em http://www.diputados.gob.mx/LeyesBiblio/pdf/2_241213.pdf, visto em 30/09/2015, às $12 \mathrm{~h} 07$.

LEGISLAÇÃO DA GUINÉ. Disponível em http://www.hcch.net/upload/cc_gn.pdf, em $01 / 10 / 2015$, às $21 \mathrm{~h} 31$.

CÓDIGO CIVIL DE QUÉBEC. Disponível em http://www2.publicationsduquebec.gouv.qc.ca/dynamicSearch/telecharge.php? type $=2 \&$ file $=/$ CCQ 1991/CCQ1991.html, acessado pela última vez em $30 / 09 / 2015$, às $13 \mathrm{~h} 31$.

LEGISLAÇÃO DA LUISIANA. Disponível em http://legis.la.gov/Legis/Laws_Toc.aspx?folder=67\&level=Parent, visto pela última vez em 27/09/2015, às 18 h07.

LEGISLAÇÃO ALEMÃ. Disponível em http://www.gesetze-iminternet.de/englisch_bgb/german_civil_code.pdf; $\quad$ e $\mathrm{http} / / \mathrm{www}$. ilo.org/dyn/natlex/docs/ELECTRONIC/61880/99080/F1903938413/DEU61880\%2 0English.pdf, consultados em 27/09/2015, às 17 h05.

LEGISLAÇÃO SUÍÇA. Disponível em https://www.admin.ch/opc/fr/classifiedcompilation/19070042/index.html\#a80, acessado pela última vez em 30/09/2015, às $14 \mathrm{~h} 11$.

CÓDIGO CIVIL HOLANDÊS. Disponível em http://www.dutchcivillaw.com/civilcodegeneral.htm, acessada pela última vez em $27 / 09 / 2015$, às $18 \mathrm{~h} 25$.

LEGISLAÇÃO JAPONESA. Disponível em http://www.moj.go.jp/content/000056024.pdf no dia $27 / 09 / 2015$, às $16 h 32$.

LEGISLAÇÃO PARAGUAIA. Disponível em http://www.oas.org/dil/esp/Codigo_Civil_Paraguay.pdf, acessado pela última vez em $27 / 09 / 2015$, às $15 \mathrm{~h} 33$.

LEGISLAÇÃO

PERUANA.

Disponível

em http://spij.minjus.gob.pe/CLP/contenidos.dll? $\mathrm{f}=$ templates $\& \mathrm{fn}=$ defaultcodcivil.htm\&vid= Ciclope:CLPdemo, no dia 27/09/2015, às 16h00.

LEGISLAÇÃO DA ARGÉLIA. Disponível em http://www.joradp.dz/TRV/FCivil.pdf, acessado em 27/09/2015, às $17 \mathrm{~h} 17$.

LEGISLAÇÃO DO TIMOR LESTE. JORNAL DA REPÚBLICA. Série 1, no 34, de 14/09/2011, e disponível para consulta em http://www.rjcplp.org/sections/informacao/anexos/legislacao-timorleste1090/codigos-e-estatutos4242/codigo-civil-timorleste/downloadFile/file/Codigo_Civil_Lei_10-2011.pdf?nocache $=1365704816.75$, visualizado pela última vez em $09 / 09 / 201 \overline{5}$, às $16: 45 \mathrm{~h}$. 
CÓDIGO CIVIL DE PORTUGAL. Disponível em http://www.pgdlisboa.pt/leis/lei_mostra_articulado.php?nid=775\&tabela=leis, consultado pela última vez em $\overline{01} / 10 / 2015$, às $14 \mathrm{~h} 35$.

LEGISLAÇÃO DE CABO VERDE. Disponível em http://www.law.yale.edu/rcw/rcw/jurisdictions/afw/capeverde/cabo_verde_codigo_ civil.htm, acessado pela última vez em 09/09/2015, às 17:14h.

LEGISLAÇÃO RUSSA. Disponível em http://www.russian-civilcode.com/PartI/SectionIII/Subsection1/Chapter23.html, acessado em 03/02/11, às $12 \mathrm{~h} 32$.

CÓDIGO CIVIL ARGENTINO. Disponível em http://www.infoleg.gob.ar/infolegInternet/anexos/235000-

239999/235975/norma.htm, acessado pela última vez em 30.09.2015, às 11 h00.

OHADA - Organisation pour 1'harmonisation en Afrique du droit des affaires, Journal Officiel de 15.02.2011, $15^{\circ}$ ano, n. 22, disponível em http://www.ohada.com/.

LEGISLAÇÃO FRANCESA. Disponível em http://www.legifrance.gouv.fr/affichCodeArticle.do;jsessionid=F5952A0DAD0352 9DA0F7FD2E6AE6DA59.tpdjo04v_3?idArticle=LEGIARTI000019293165\&cidT exte $=$ LEGITEXT000006070721\&dateTexte $=20110711$, visitado pela última vez em 30.09.2011, às $11 \mathrm{~h} 24$.

FRANÇA. Conseil d'État. Arrêt du conseil d'état du Roi qui casse et annulle un arrêt du parlement de Bordeaux du 27 août 1760, par lequel fait défenses aux commis à la recette des droits de contrôle et d'insinuation, de percevoir lesdits droits pour les clauses de reprise de bagues, de joyaux et autres ornements, d. 1761. Disponibilizado pela Bibliothèque nationale de France através do endereço www.gallica.bnf.fr, acessado em 03.07.2014, às 09h09.

CORTE INTERAMERICANA DE DIREITOS HUMANOS. Sentença do caso Awas Tingni Community vs. Nicaragua, disponível em http://www.corteidh.or.cr/docs/casos/articulos/seriec_79_ing.pdf, acessado pela última vez em 20.08.2015, às 14:45h.

BRASIL. Congresso Nacional. Projeto de Lei $\mathrm{n}^{\circ}$ 634/75. Disponível em http://www.camara.gov.br/proposicoesWeb/fichadetramitacao?idProposicao=1567, consultado pela última vez em 27/06/2011, às 12:01h.

BRASIL. Lei de 20 de outubro de 1823. Disponível em http://www2.camara.leg.br/legin/fed/lei_sn/anterioresa1824/lei-40951-20-outubro1823-574564-publicacaooriginal-97677-pe.html, acessado em 08.12.2015, às 17 h50.

ACADEMIA BRASILEIRA DE LETRAS. Vocabulário Ortográfico da Língua Portuguesa - VOLP. Acessível no endereço http://www.academia.org.br/nossa-lingua/buscano-vocabulario.

ACADEMIA BRASILEIRA DE LETRAS, mensagem eletrônica datada de 14.12.2015.

TRIBUNAL SUPERIOR DO TRABALHO, consulta de jurisprudência realizada na página http://www.tst.jus.br/consulta-unificada, em diversas datas. 
SUPERIOR TRIBUNAL DE JUSTIÇA, pesquisa de súmulas e jurisprudência realizada na página http://www.stj.jus.br/SCON/, em diversas datas.

SUPREMO TRIBUNAL FEDERAL, pesquisa de súmulas e jurisprudência realizada na página http://www.stf.jus.br/portal/jurisprudencia/pesquisarJurisprudencia.asp, em diversas datas.

\section{Outros}

AGUIAR JUNIOR, Ruy Rosado de. Jornada de Direito Civil. Brasília: CFJ, 2007.

Cópia dos esboços originais do Projeto de Código Civil coordenado pelo prof. Miguel Reale com as anotações introduzidas por ele, fornecidas pelo prof. José Fernando Simão. 